\title{
The Body of the Soul. \\ Lucretian Echoes in the Renaissance Theories on the Psychic Substance and its Organic Repartition*
}

Fabio Tutrone

\section{Summary}

In the $16^{\text {th }}$ and $17^{\text {th }}$ centuries, when Aristotelianism still was the leading current of natural philosophy and atomistic theories began to arise, Lucretius' De Rerum Natura stood out as an attractive and dangerous model. The present paper reassesses several relevant aspects of Lucretius' materialistic psychology by focusing on the problem of the soul's repartition through the limbs discussed in Book 3. A very successful Lucretian image serves as fil rouge throughout this survey: the description of a snake chopped up, with its pieces moving on the ground (Lucretius DRN 1969, 3.657-669). The paper's first section sets the poet's theory against the background of ancient psychology, pointing out its often neglected assimilation of Aristotelian elements. The second section highlights the influence of De Rerum Natura and its physiology of the soul on Bernardino Telesio, Agostino Doni and Francis Bacon, since all of these authors engage in an original recombination of mechanical and teleological explanations.

Keywords: Lucretius, Aristotle, dissections, Telesio, Doni, Bacon

\footnotetext{
* This article is dedicated to the loving memory of Prof. Domenico Romano, whose exceptional teaching introduced me to the study of Lucretius' work and its multifaceted reception.
}

Fabio Tutrone, Università di Palermo, Dipartimento di Scienze Umanistiche, Viale delle Scienze, Edificio 12, I-90128 Palermo (fabio.tutrone@unipa.it) 


\section{Between conflict and assimilation. Lucretius, Aristotle, and the physiology of the soul}

In one of John Donne's most famous Holy Sonnets, the heart of the poet is described as a besieged town waiting for divine liberation. Reason is the viceroy of God in the human body and a celestial rape is invoked in order to work out the author's spiritual salvation:

Batter my heart, three person'd God; for, you

As yet but knocke, breathe, shine, and seeke to mend;

That I may rise, and stand, o'erthrow mee, 'and bend

Your force, to breake, blowe, burn and make me new.

I, like an usurpt towne, to'another due,

Labour to'admit you, but Oh, to no end,

Reason, your viceroy in mee, mee should defend,

But is captiv'd, and proves weake or untrue.

Yet dearely'I love you, and would be lov'd fain,

But am betroth'd unto your enemie:

Divorce mee, 'untie, or break that knot againe,

Take mee to you, imprison mee, for I

Except you'enthrall mee, never shall be free,

Nor ever chast, except you ravish mee. ${ }^{1}$

The paradoxical and visionary taste of Donne's metaphysical poetry might be simply regarded as a literary device. However, it is noteworthy that some basic traits of such a powerful imagery are shared by the tradition of scientific physiology. When trying to explain the constitution and functions of the soul, ancient and modern philosophers interested in natural science frequently appealed to various kinds of metaphors. For instance, Francis Bacon, who belonged to the same generation as Donne, compared the psychic substance placed in the human brain (spiritus vitalis) to a Senate ruling the organs as well as to the holder of a University chair. ${ }^{2}$ Clearly, the need to elucidate obscure phenomena such as the psychic life of animals led to employ a large range of analogies and figures. Even more important, this explanatory trend did not begin in the modern age (though Baroque mannerism was remarkably inclined to it); on the contrary, it was the legacy of Greek and Roman writers, greatly appreciated in the Renaissance, who had dealt in depth with the physiology of the soul.

1 J. Donne, Holy Sonnets, XIV.

2 Cf. Bacon 1611-19, 158 (senatus) and Bacon 1623a, 454 [\$ 40] (cathedra et universitas). See also Bacon 1623b, 352 (rector et quasi auriga sit imaginatio). Developing an Aristotelian image, Telesio 1586, V, 27 (362-365) describes animals as cities, and the soul as their ruler (princeps). On Bacon's conception of spiritus vitalis see Walker 1972, Rees 1984 and Fattori 1984. A wide contextualization of the problem can be found in Clericuzio 1988. 
In the present article I shall be discussing the interactions between such classical models, their own internal composition, and some modern revivals. More precisely, I will investigate the impact of Lucretius' view of the soul and its material distribution on Bernardino Telesio, Agostino Doni and Francis Bacon. These three Renaissance men of science are particularly representative of the varied responses to the psychology of De Rerum Natura which characterize the $16^{\text {th }}$ and $17^{\text {th }}$ centuries scientific debate.

In an age when Aristotelianism still was the leading current of natural philosophy (despite its own process of doctrinal transformation) ${ }^{3}$ and atomistic theories began to arise, Lucretius' poem stood out as an attractive and dangerous model. ${ }^{4} \mathrm{Jt}$ bore witness to Epicurus' physics and was conspicuous for its didactic efficacy as well as for its "scandalous" antireligious claims. ${ }^{5}$ However, my point here won't be the influence of De Rerum Natura on the development of modern atomism, nor will I discuss the poem's features as a literary and aesthetic paradigm. I will reassess several relevant aspects of Lucretius' materialistic psychology, by focusing on the problem of the soul's repartition through the limbs discussed in Book 3. A very successful Lucretian image will serve as fil rouge throughout this survey: the description of a snake chopped up, with its pieces moving on the ground. ${ }^{6}$ First, I will set the poet's theory against the background of ancient psychology, pointing out its often neglected assimilation of Aristotelian elements. Second, I will try to highlight the importance of De Rerum Natura and its physiology of the soul to the thought of Telesio, Doni and Bacon, who variously combine mechanical and teleological explanations.

3 A clear-cut opposition between the academic supporters of Aristotelianism and the new theorists of natural science would certainly distort our understanding of the Renaissance debate. In the $16^{\text {th }}$ and $17^{\text {th }}$ centuries, the study of Aristotle's texts and the practice of his scientific method were still central to the culture of official institutions. But even if eminent exponents of the so-called scientific revolution engaged in a daring confutation of influential Peripatetic ideas, it would be a mistake to see Renaissance Aristotelianism as an epigonic form of Scholasticism. Indeed, several Peripatetic-oriented authors of this age took part in an eclectic renovation of Aristotle's doctrine (with special regard to physics) and defended the autonomy of philosophical research. See e.g. Schmitt 1973 and Gambino Longo 2004, 121-177.

4 Lucretius' imagery and arguments exerted a profound influence on the rise of modern atomism. Meinel 1988 listed the circulation of De Rerum Natura among the three main reasons for the success of corpuscularian theories in the $16^{\text {th }}$ and $17^{\text {th }}$ centuries. On the poem's Fortleben as a source for atomic physics, however, see also Stückelberger 1972 and Johnson/Wilson 2007.

5 The Renaissance reception of De Rerum Natura as a paradigm of didactic poetry and a potential incitement to heresy is widely discussed by Prosperi 2004 and Paladini 2011. A comprehensive survey on Lucretius' revival from the late Middle Ages to the $17^{\text {th }}$ century can now be found in Passannante 2011, where special emphasis is put on the poet's "materialistic" comparison between letters and atoms. Interestingly, Passannante highlights the impact of De Rerum Natura on fourteenth-century writers like Petrarch and Boccaccio, who knew the poem only through the mentions of later Latin authors.

6 See Lucretius DRN 1969, 3.657-669, reported below. 
Let us start with the vivid verses of Epicurus' Roman disciple. ${ }^{7}$ According to Lucretius, the soul of every living being is an atomic aggregate performing a double function: the so-called animus directs all rational activities, supervises sensory perception, and resides in the middle of the chest ("media regione in pectoris", 3.140), while the anima is spread out through the whole body ("per totum dissita corpus", 3.143) and allows different vital faculties. ${ }^{8}$ Of course, there is a unitary mortal soul in each organism, the distinction just outlined being of a merely functional nature. ${ }^{9}$ The life of men and animals depends mainly on the animus, which is the actual core of psychic activities ("caput esse quasi et dominari in corpore toto", 3.138), whereas parts of the anima can be removed together with the limbs which host them. ${ }^{10}$ The fact that a snake survives after it has been chopped up and that its shreds writhe on the soil is said to demonstrate the mortal and divisible nature of atomic souls:

Now let's consider a snake, with flickering tongue,

Long Body, and menacing tail. Take your knife

And cut it up. You'll see the separate parts

All writhing while the wound is fresh,

Spattering the earth with gore. See how its head

Turns round and back and tries to gnaw its tail,

Wanting to bite away the burning pain.

Shall we then say in each separate piece

There is a separate spirit? If we do,

That means that in one single animal

There are many spirits spread throughout the body.

It follows that one single spirit has been

Divided, just as the body has, so each

Must be considered mortal, since they both

Have been alike cut into many parts. ${ }^{11}$

7 The long section of Book 3 devoted to material psychology is 94-829. A careful assessment of Lucretius' psychological treatment should always be based on a comparison with Epicurus' own discussion in Ep. 2.63-68 as well as with the fragments collected in Usener 1887, 216-225.

8 See also the scholium to Epicurus, Ep. 2.66.

9 Cf. 3.136-137; 3.416.

10 Cf. Epicurus, Ep. 2.65 (transl. by Inwood/Gerson 1994, 13): "That is why the soul, as long as it is in [the body], will never lack sense-perception even if some other part has departed; but no matter what parts of it are destroyed along with the container's dissolution (whether entire or partial), if the soul survives it will be able to perceive ( $\sigma \dot{\omega} \zeta \varepsilon \imath \tau \eta \eta े v ~ \alpha i \sigma \theta \eta \sigma v)$. But the rest of the aggregate $(\ddot{\alpha} \theta \rho o \iota \sigma \mu \alpha)$ - whole or part - is not able to perceive even if it survives, when the number of atoms, however small it be, which makes up the nature of the soul, has departed

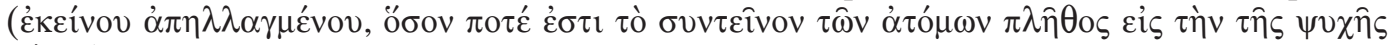

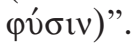

11 Lucretius DRN1969,3.657-669: “Quin etiam tibi si, lingua vibrante, minanti I serpentis cauda, procero corpore, utrumque I sit libitum in multas partis discidere ferro, | omnia iam sorsum cernes ancisa recenti | volnere tortari et terram conspargere tabo, I ipsam seque retro partem petere ore priorem, | volneris ardenti ut morsu premat icta dolore. I Omnibus esse igitur totas dicemus in illis I particulis animas? At ea ratione sequetur I unam animantem animas habuisse in corpore multas. I Ergo divisast ea quae fuit una simul cum I corpore; quapropter mortale utrumque putandumst, I in multas quoniam partis disciditur aeque." Here and elsewhere, I report the text of J. Martin's Teubner edition (Lucretius DRN 1969). English translations are those of Melville 1997. 
The use of biological evidence in order to support atomic theories is a distinctive feature of Lucretius' didactic technique, a feature that will meet with considerable successful among modern corpuscularians. ${ }^{12}$ It has even been argued that such a careful focus on biology reflects the poet's personal interests and makes an innovatory contribution to the development of Epicurean science. ${ }^{13}$ The fragmentary state of our sources suggests caution in asserting Lucretius' novelty, and a thorough Quellenforschung concerning the arguments of Book 3 is beyond the scope of the present paper. Nevertheless, the passage just quoted allows to elucidate several significant points.

First of all, the interpretation of zoological data proves to be central to Lucretius' psychological exposition. The case of the snake is intended to illuminate the condition of every living being as an organism endowed with a soul. Human beings do not figure in a separate class, neither is their fate presented as different. On the contrary, after a comprehensive introduction (3.634-641), the section immediately preceding our argument points to the occurrence of the same phenomenon on battlefields (3.642-656): in a rather macabre description, the poet introduces the example of warriors who are unaware of a sudden mutilation, even if their limbs tremble on the ground. ${ }^{14}$ Such a resolute assimilation of human and animal physiology is typical of Lucretius' thought, as attested by numerous passages in the poem. ${ }^{15}$ By remarking that men and beasts share a common constitution, the author strengthens his fundamental ethical belief: if man is nothing but a rational animal, and reason itself is a material hereditary character, ${ }^{16}$ then any

12 In his discussion of early 17th-century atomism, Meinel 1988, 103 rightly emphasizes "the persuasive appeal of the pictorial scheme supplied by Lucretius's poetic imagery, which offered an immediately convincing way of picturing material processes on the basis of everyday experience within the visible world". In a previous paper (Tutrone 2012a), I attempted to connect this remarkable aspect of the poem's Nachleben with the particular structure of Lucretius' own scientific method.

13 See Schrijvers 1999, who points out "l'absence totale de thèmes biologiques dans la reconstruction du Peri phuseôs d'Epicure, telle qu'elle a été proposée par D. Sedley et généralement reprise par M. Erler" (46). Although our incomplete knowledge of the Epicurean tradition does not allow any certain assumption, Lucretius' inclination to life sciences is indeed striking. The poet seems to employ the macroscopic experience of organic functions as a preferential field for his physical arguments. See also Pigeaud 1980 (and 1981, 196 ff.), who puts special emphasis on Lucretius' skilfulness in combining "mécanisme" and "vitalisme", mechanical explanations and biological remarks.

14 Violent amputations are mentioned as an argument of psychological significance by Diogenes of Oenoanda, fr. 37 Chilton, coll. 3.2-10. However, the fact that living beings survive mutilations is recalled by Diogenes in order to prove the primacy of the soul in the body-soul relationship. See Chilton 1971, 91-94, and Ferguson Smith 1993, 486-488.

15 For an all-encompassing discussion see Tutrone 2012b, 29-154.

16 See 3.741-753, where human reasoning (sapere) is opposed to animal irrationality (desipere), but both are seen as hereditary traits. In Lucretius' view, men transmit their logical faculties in the same way as every species hands down its typical inclination (aggressiveness for lions, fraud for foxes etc.). 
providential cosmology is to be rejected in accordance with Epicurus' liberating message. In the context of our passage, the careful demonstration of the divisibility of the soul is aimed to prove the mortal nature of man's inner essence ${ }^{17}$ thus freeing the reader from his eschatological fears. According to Lucretius, any theory on the survival of the soul is physically unfounded and ethically misleading. Doctrines like metempsychosis ${ }^{18}$ for instance, are mistakes that worsen the fear of death and post-mortem sufferings.

Given such "irreligious" implications, it is easy to imagine the difficulties experienced by Lucretius' Renaissance imitators. On the one hand, the psychology of De Rerum Natura was an innovatory and tempting model, a real mine of physiological information. On the other hand, however, the poet's discussion involved a number of assumptions which were totally incompatible with Christianity and could not be accepted in any Catholic or Protestant country. Already in fifteenth-century Florence, Lucretius' claims against the belief in an afterlife sounded very suspicious. ${ }^{19}$ As we shall see, the prudent solution found by Renaissance thinkers such as Bacon and Telesio consisted in a "double-levelled" treatment of psychology. The Lucretian distinction between animus and anima, rational coordinating soul and bodily faculties, was readapted into a more clearly metaphysical dichotomy, which opposed the rational, eternal soul created by God to a material principle generated from the semen ${ }^{20}$ However, before approaching directly such modern receptions, it is useful to expound in more detail other relevant aspects of Lucretius' text. More attention should be paid to the poet's theoretical background as well as to the sources of his imagery, since far from being an original Lucretian pattern, the case of animals surviving a dissection had been variously employed in the tradition of ancient psychology.

The most prominent author to be recalled in this regard is certainly Aristotle. The Stagirite was an influential model in the field of natural sciences when Epicurus conceived his atomistic system, later propagated by Lucretius. And he was an established authority in physics when De Rerum Natura reappeared in modern age Europe. Therefore, it is especially interesting to compare Lucretius' treatment with Aristotle's references to dissected animals in De Anima. Three passages from Books 1 and 2 of De Anima

17 Cf. also 3.640-641: "at quod scinditur et partis discedit in ullas,/ scilicet aeternam sibi naturam abnuit esse."

18 Cf. $3.670 \mathrm{ff}$.

19 See the survey of Brown 2010: One of Lucretius' aims was to rid people of the fear of death and the retribution that it threatened. This was also one of his attractions, as well as one of the most dangerous implications of his philosophy, in removing the sanctions of the afterlife that rewarded the good and punished the wicked (viii).

20 See Gemelli 1996, 106 ff. 
seem to deserve particular attention, as they throw light on central concerns of the ancient psychological debate. As is well-known, the first book of De Anima contains a polemical discussion of earlier conceptions of the soul, including Democritus' atomistic psychology, which is decidedly rejected. ${ }^{21}$ This fact is not unrelated to our present interest, since Epicurus' and Lucretius' materialistic tenets admittedly develop Democritean premises. ${ }^{22}$

We may start with a passage where Democritus is explicitly mentioned and the case of plants and animals surviving a dissection is used against him. Indeed, Aristotle's criticisms tendentiously assimilate Xenocrates' and Democritus' theories on the basis of their common quantitative approach. Xenocrates is said to have seen the soul as a self-moving number, namely as a definite quantity placed in a given space. ${ }^{23}$ This enables Aristotle to treat Democritus' psychology in the same context. Both numbers and atoms, in fact, are presented as magnitudes which can be reduced or increased, and a similar condition is said to contrast with our evidence on the nature of the soul:

Again, if from a number a number or a unit is subtracted, the remainder is another number; but plants and many animals when divided continue to live, and each segment is thought to retain the same kind of soul. It must be all the same whether we speak of units or corpuscles; for if the spherical atoms of Democritus became points, nothing being retained but their being a quantum, there must remain in each a moving and a moved part, just as there is in what is continuous; $;{ }^{24}$ what happens has nothing to do with the size of the atoms, it depends solely upon their being a quantum..$^{25}$

21 Book 1 of De Anima is often neglected by readers interested in Aristotle's own view of the soul, whereas its doxographical contents have been hugely exploited. As Witt 1992 pointed out, however, in this opening section "the method of dialectic collects and evaluates endoxacommon opinions and the opinions of the wise - in order to shape and direct the inquiry that follows. Book 1 of the De Anima, therefore, is also an important source for our understanding of Aristotle's views on the nature of soul" (169).

22 As Epicurus' beloved pupil Metrodorus seems to have said in his On Philosophy, "if Democritus had not led the way, Epicurus would not have attained wisdom" (Plutarch, Adv. Colot. $3.1108 \mathrm{e}-\mathrm{f})$. A collection of testimonies dealing with the relationship between Democritus and the Epicurean tradition can be found in Taylor 1999, $150 \mathrm{ff}$. It may be useful to cite here Cicero's claim (Nat. deor. 1.73) that the greatest part of Epicurus' physical doctrines (pleraque) derived from Democritus (cf. also Fin. 1-17-18; 20-21; 2.102; 4.13; Acad. 1.6). Even if this contention involves a strong dose of polemical exaggeration, it can be compared to Lucretius' praise of Democritus as a sacred hero (Democriti sancta viri sententia, $3.371 ; 5.622$ ) unafraid of death (3.1039-1041). It is perhaps no accident that similar eulogies occur in the psychological exposition of Book 3: Epicurus' idea of the soul was greatly indebted to that of the earlier atomists, and both Lucretius and Cicero were deeply aware of such affinities.

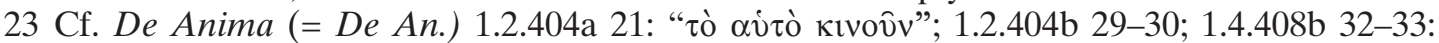

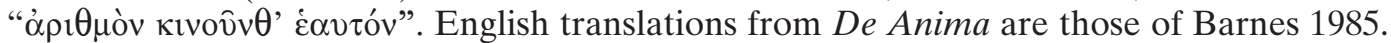
On Xenocrates' psychology see the fragments collected by Isnardi Parente 1982, 116-130 (with the commentary at 382-400).

24 Cf. Aristotle's theory on motion in Phys. 257b 2-13.

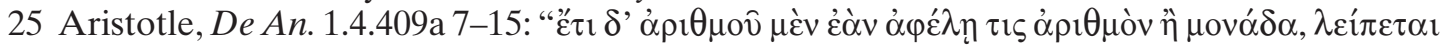

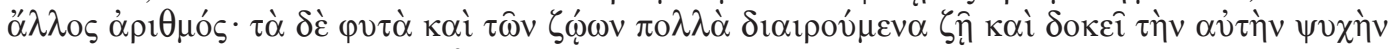

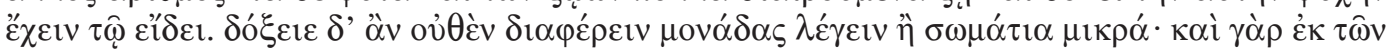


The passage goes on with other objections to the same view, whose distance from Aristotle's hylomorphism is patent. While the Stagirite defines the soul in terms of form (عî่os), ${ }^{26}$ developing a functional and teleological psychology which has been compared to modern functionalism, ${ }^{27}$ the supporters of mathematical and corpuscular conceptions see the psychic substance as a spatial quantum. However, it is wise to forsake Aristotle's combination of Democritean and Xenocratean ideas, which is mostly founded on polemical assumptions. What is of greater interest for us is the Aristotelian appeal to the dissection of animals in the framework of an antiatomistic theory. In fact, the survival of cut up living beings is mentioned to confirm the homogeneity of the soul from a formal point of view, that is, in a functional and qualitative sense. Any atomic fragmentation of the $\psi v \chi \eta$ is categorically excluded.

Seen in this light, Lucretius' use of the same argument for the sake of a mechanical psychology sounds like a polemical reversal. One might also wonder whether Democritus himself had appealed to dissections in order to corroborate his theory, but there is no clear evidence to support a similar hypothesis. ${ }^{28}$ For the purposes of the present paper, it will suffice to use Aristotle's refutation of Democritus as an emblematic starting point, since

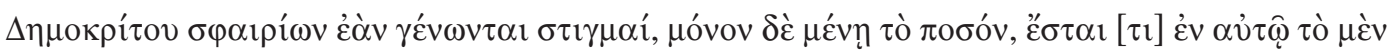

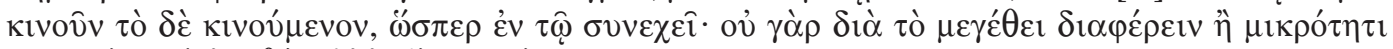

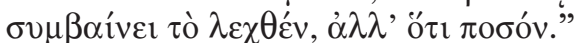

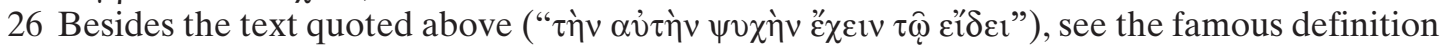
of $D e A n$. 2.1.412a 19-21, which describes the soul as "a substance in the sense of form of

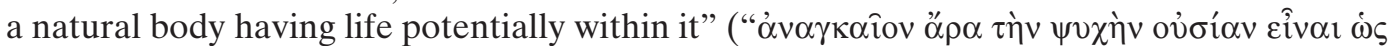

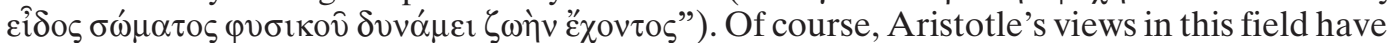
been variously interpreted and discussed by scholars: several insightful surveys can be found in Nussbaum/Oksenberg Rorty 1992 and Granger 1996.

27 Among the most well-known upholders of a functionalist interpretation of Aristotle's psychology are Putnam 1975 and Nussbaum 1978, but this line of thought has been opposed by scholars like Burnyeat 1992. For a recent re-discussion see Cohen 1992 and Patzig 2009.

28 We know that according to Democritus the soul is spread out through the whole body: see e.g. Aristotle, De An. 1.5.409a $31 \mathrm{ff}$. and Sextus, Adv. math. 7.349. Lucretius is aware of this doctrine, but rejects the Democritean idea of an alternation between bodily and psychic atoms in the limbs (3.370-373). Moreover, like many other Presocratic philosophers, Democritus employed inductive analogies in order to elucidate his system (see Lloyd 1971, esp. 337-341): in one of these analogies, he compared the atomic structure of things with the composition of words on the basis of letters (see e.g. Aristotle, Met. 985b 13-19; De gen. et corr. 315b 15). The same argument is repeatedly exploited by Lucretius, whose natural philosophy has been depicted by some interpreters as a "cosmic grammar" (see Dionigi 1988, 2008, and Snyder 1980, esp. 31 ff.). In more general terms, the use of analogies is a central pattern of De Rerum Natura and its scientific investigations (see Schrijvers 1978, Asmis 1984 and Schiesaro 1990). Garani 2007 has also pointed out relevant similarities between Empedocles' and Lucretius' analogical methods, thus showing the importance of Presocratic models to the poem's imagery. Finally, it may be worth noticing that Philoponus, In De gen. animal. $1.4 .739 \mathrm{~b} 33$, p. $10027 \mathrm{ff}$, referred to the evidence of dissections ( $\dot{\alpha} v \alpha \tau o \mu \alpha \grave{i})$ in order to defend Aristotle's views on the hearth and its functions against the objections of Democritus. 
such a refutation shows that in the ancient scientific debate the very same piece of evidence could serve as medium for conflicting conceptions. ${ }^{29}$

It is no accident that in another passage of De Anima Aristotle presents the case of plants and animals as entirely consistent with his hylomorphic psychology. He maintains that in spite of its functional differentiation the soul cannot be really divided, for its form or species ( $\varepsilon_{i} \delta \circ \varsigma$ ) is unitary and homogeneous:

Some hold that the soul is divisible, and that we think with one part and desire with another. If, then, its nature admits of its being divided, what can it be that holds the parts together? Surely not the body; on the contrary it seems rather to be the soul that holds the body together; at any rate when the soul departs the body disintegrates and decays. [...] The question might also be raised about the parts of the soul: What is the separate role of each in relation to the body? For, if the whole soul holds together the whole body, we should expect each part of the soul to hold together a part of the body. But this seems an impossibility; it is difficult even to imagine what sort of bodily part thought will hold together, or how it will do this. It is a fact of observation that plants and certain insects go on living when divided into segments; this means that each of the segments has a soul in it identical in species, though not numerically; for both of the segments for a time possess the power of sensation and local movement. That this does not last is not surprising, for they no longer possess the organs necessary for self-maintenance. But, all the same, in each of the parts there are present all the parts of soul, and the souls so present are homogeneous with one other and with the whole - the several parts of the soul being inseparable from one other, although the whole soul is divisible. ${ }^{30}$

Again, the spectre of atomism surfaces in Aristotle's text, and the evidence emarging from dissections is invoked to confirm a formal approach. Although, to a limited extent, Aristotle admits a "numerical" distribution of the psychic substance $(\dot{\alpha} \rho \theta \mu \hat{\omega})$, this phenomenon regards a secondary aspect of the physiological explanation. The philosopher's main concern is to reaffirm the soundness of hylomorphism as a comprehensive account, the soul performing different functions that do not correspond to different material parts. Generally speaking, a holistic concept of psychic life prevails, and the fact that chunks of living beings maintain sensation and local movement is deprived of any

29 Even the above-cited analogy between letters and atoms, for instance, was resumed and ridiculed by the opponents of Epicureanism: see Cicero, Nat. deor. 2.93, Plutarch, De Pyth. Orac. 399E, and the comments of Snyder 1980, 35-37.

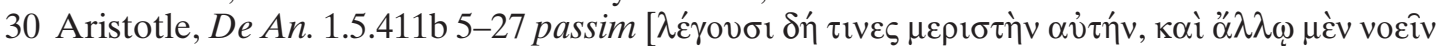

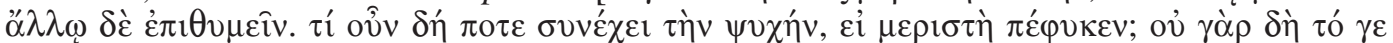

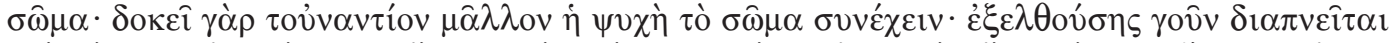

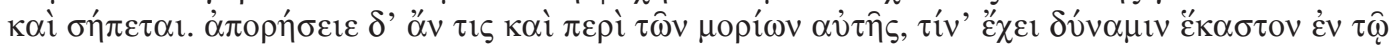

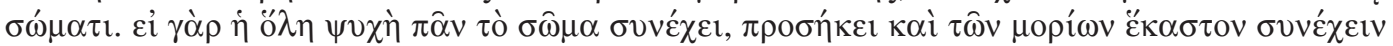

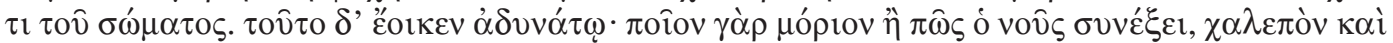

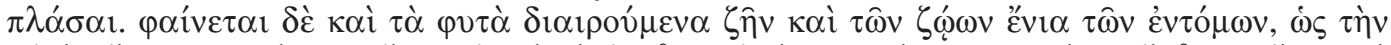

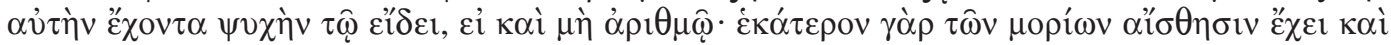

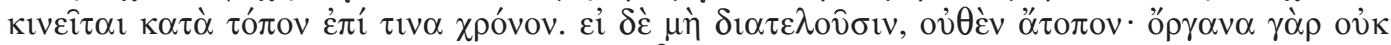

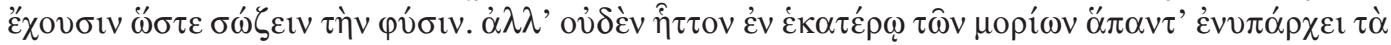

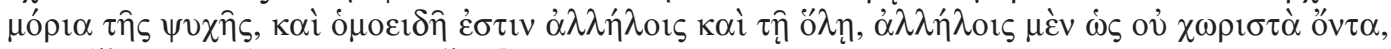

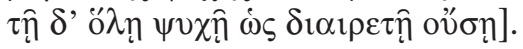


possible mechanical implications. ${ }^{31}$ The Stagirite expressly remarks that no biological fragment survives for a long time, since the lack of proper organs

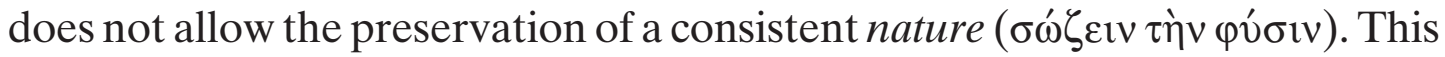
is a core aspect of Aristotle's argument, for it is strictly connected to his systemic and functional view of physiology. An analogous attitude comes out also from a passage in Book 2. When discussing the subdivision of the soul into different parts or faculties ( $\mu$ ópı $\alpha, \delta v v \alpha ́ \mu \varepsilon ı \varsigma$ ), the philosopher states that even complex activities such as desire, pleasure and imagination may be contained in single limbs of living beings. Nevertheless, he explains such cases of psychological fragmentation in terms of form and hylomorphic relationships:

At present we must confine ourselves to saying that soul is the source of these phenomena and is characterized by them, viz. by the powers of self-nutrition, sensation, thinking, and movement. Is each of these a soul or a part of a soul? And if a part, a part merely distinguishable by definition or a part distinct in local situation as well? In the case of certain of these powers, the answers to these questions are easy, in the case of others we are puzzled what to say. Just as in the case of plants which when divided are observed to continue to live though separated from one another (thus showing that in their case the soul of each individual plant was actually one, potentially many), so we notice a similar result in other varieties of soul, i.e. in insects which have been cut in two; each of the segments possesses both sensation and local movement; and if sensation, necessarily also imagination and appetition; for, where there is sensation, there is also pleasure and pain, and, where these, necessarily also desire. We have no evidence as yet about thought or the power of reflexion; it seems to be a different kind of soul, differing as what is eternal from what is perishable; it alone is capable of being separated. All the other parts of soul, it is evident from what we have said, are, in spite of certain statements to the contrary, ${ }^{32}$ incapable of separate existence though, of course, distinguishable by definition. ${ }^{33}$

31 As Wilkes 1992, 110 pointed out, in Aristotle's psychology "the capacities that constitute the psuce interlock and help determine the nature of each other; they are not disjointed, like beads on a string". Indeed, it is likely that "Aristotle was the first to take note of «the holism of the psychological» - or more generally, of the psuche-logical”.

32 Plato and his tripartite psychology can be easily recognized as one of Aristotle's targets. As is well-known, in Timaeus, $69 \mathrm{~d}$ ff. the different parts of the soul are said to have been placed

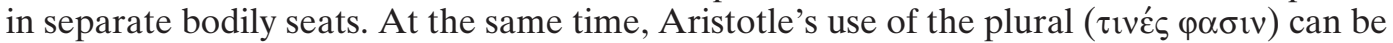
taken as a reference to a larger group of thinkers. Such a group may well include every supporter of a material distribution of soul, from the Presocratics to Plato's followers. Democritus, for instance, seems to have placed the rational part of the soul in a specific seat (cf. Aët. 4.4.6; 4.5.1; Theodoret. 5.22).

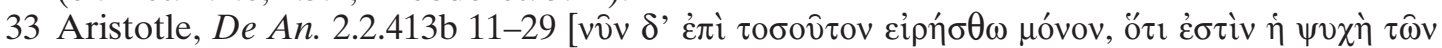

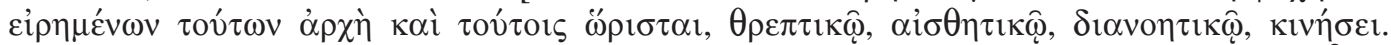

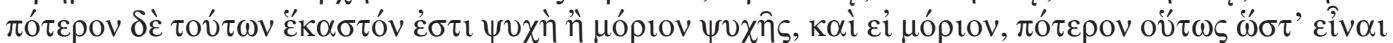

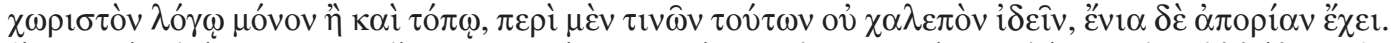

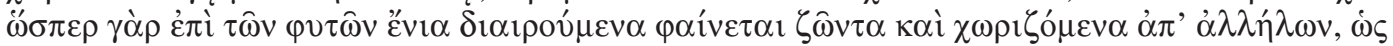

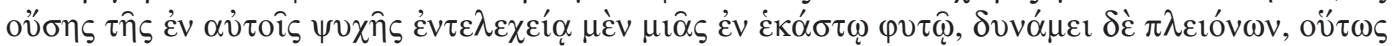

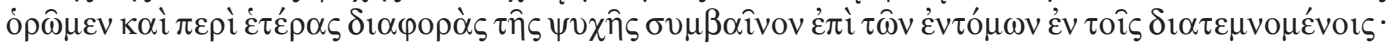

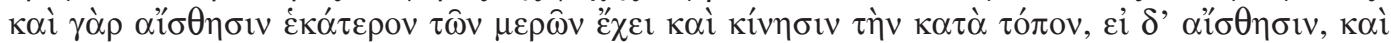

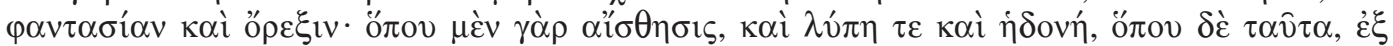

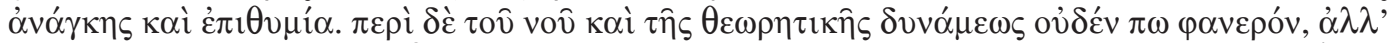

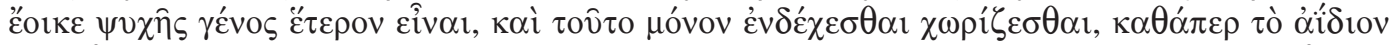

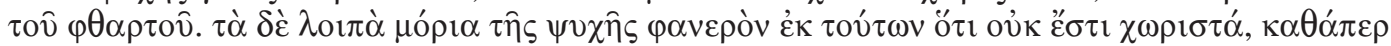

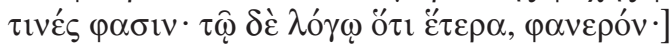


Aristotle perceives and points out the intrinsic difficulty of the topic ( $\ddot{\varepsilon}^{\prime} v 1 \alpha \delta \dot{\varepsilon}$

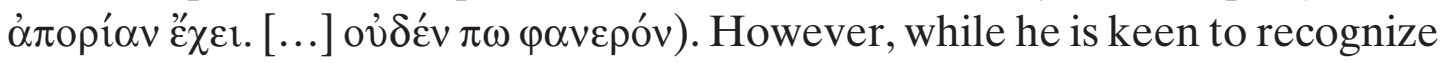
a logical or conceptual division of the psychic faculties $(\lambda o ́ \gamma \omega)$, he rejects the possibility of a local and mechanical repartition ( $\tau$ ó $\pi \omega)$. What is more, the evidence provided by plants and insects is carefully integrated into the teleological view of the soul as entelechy ( $\dot{\varepsilon} v \tau \varepsilon \lambda \dot{\varepsilon} \chi \varepsilon 1 \alpha)$. On the one hand, relevant features of animal life such as imagination $(\varphi \alpha \nu \tau \alpha \sigma i \alpha)$ and appetition (óp $\varepsilon \xi 1 \zeta)$ are said to persist in organic segments, since they descend from sense perception ( $\alpha$ i $\sigma \theta \eta \sigma 1 \varsigma$ ), which is present in single limbs. On the other hand, the genesis of this phenomenon is seen in the typically Aristotelian opposition between matter and form, potentiality and actualization. An undivided living being possesses one soul, which acts as the end of the body and directs

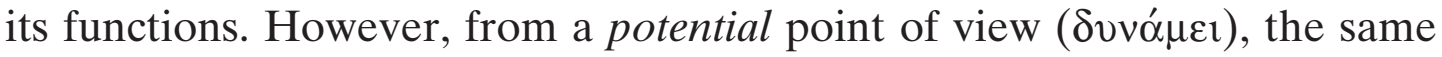
organism may contain different souls which events like a cut activate. This happens in the case of plants, whose simple psychic structure does not include sensation ${ }^{34}$ and can be easily reproduced.

After the cutting of a plant originates an independent body, this creates a new formal balance and develops its own soul. In fact, given the deeply holistic nature of Aristotle's psychology, his remarks on local faculties - though significantly careful - inevitably reflect such a framework. ${ }^{35}$ The only aspect of the Stagirite's theory that seems to escape holistic and hylomorphic

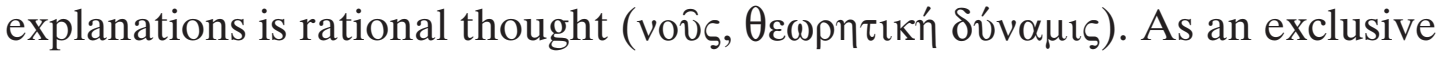
prerogative of human beings, reason transcends the limits of perishable matter and reveals a divine character. ${ }^{36}$ It has been persuasively shown

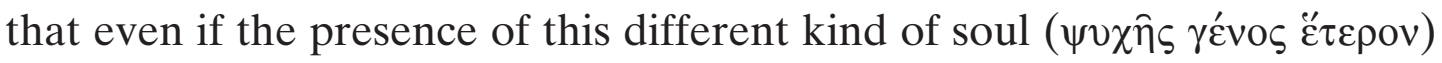
generates a tension within Aristotle's account, the philosopher runs the risk of such an ambiguity in order to "do justice to our split nature as human beings". ${ }^{37}$ As members of the animal kingdom, the Stagirite argues, we are endowed with a hylomorphic soul teleologically directing our functions. At the same time, the possession of intellect (vov̂s) and language ( $\lambda$ ó $\left.{ }^{\circ} \varsigma\right)$ dis-

34 Cf. De An. 1.5.411b 27-30.

35 See Lloyd 1992, 153-154: "of course the extent to which Aristotle's account of parts of the body proceeds by reference to the faculties of the soul varies a great deal. That feature of his approach is at its most prominent in such a case as the heart, seen by Aristotle as the controlling principle of the living creature [...]. But even when a part is not directly linked to a specific faculty of the soul it may, and generally does, serve such faculties indirectly or the general well-being of the living creature as a whole".

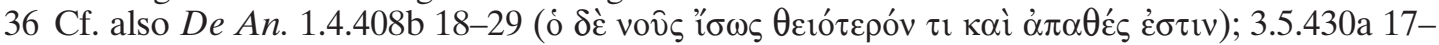
25 , where the author draws his famous distinction between active and passive intellect, and

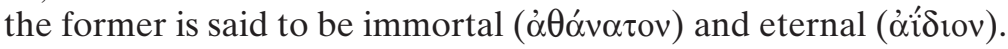

37 Cf. Kahn 1992, 361. 
tinguishes man from other animals and admits him into the realm of culture. This would actually be our incorporeal and eternal essence.

As is well-known, such a comprehensive approach, which sharply combined physiology and transcendence, determined Aristotle's appeal over the centuries to come. Before turning to the modern age debate, however, it is worth paying closer attention to the origins of Epicurean psychology. Already in the seventies, Carlo Diano pointed out Epicurus' huge debt to the Stagirite's view of the soul, and much of the evidence he gathered came from Lucretius' poem. ${ }^{38}$ Diano was especially careful in demolishing widespread commonplaces about Democritus, Epicurus, and Aristotle. As a rule, in fact, historians of ancient philosophy assume a continuous connection between the earlier Atomists and Epicurus. It is often argued that in spite of its several corrections to Democritus' model, Epicurean physics largely relies on previous atomistic ideas. ${ }^{39}$ Even more important, such an intellectual kinship is usually contrasted with Hippocrates' and Aristotle's legacy. ${ }^{40}$ Although this line of interpretation is founded on basic truths (first of all, the gap between continuum theorists and corpuscularians), its thoughtless generalization can be highly misleading. As Diano and other scholars have shown, the birth and development of Epicurean philosophy would have never been possible without Aristotle's thought. ${ }^{41}$

As regards the field of psychology, the key link between Epicurus' and Aristotle's theories lies in the representation of the body-soul relationship. In fact, though Democritus' explanation of psychic life in terms of atoms and material processes lays the foundations of Epicurean psychology, his relationship to Presocratic hylozoism marks a crucial difference from Epicurus' mechanistic approach. ${ }^{42}$ Even a polemic Christian author like

38 Diano 1974.

39 As mentioned earlier, many Greek and Roman writers tend to emphasize this philosophical ancestry (cf. above n. 22).

40 See e.g. Furley 1966,31-32, who constructs a sharp opposition between the "Aristotelians" and the "Atomists". The same division is widely exploited in Furley 1989. Likewise, Pigeaud 1980, 177, discusses the contrast between "vitalisme" and "mécanisme" in ancient physiology.

41 In recent years, numerous surveys have investigated Epicurus' debt to Aristotle and the Peripatic tradition - far beyond the problematic thesis of Bignone 1973, who restricted the range of his analysis to the influence of Aristotle's exoteric writings. It may suffice to mention Gigante 1999, who summarizes some of the most important results of previous scholarship, and Mansfeld 1994, who offers valuable insights into Epicurus' re-use of Peripatetic physics.

42 The connection between Democritus and the typically Ionic-Presocratic view of matter as a vital entity has been recently recalled by Rechenauer 2009, who provides a careful reconstruction of Democritean psychology. As Rechenauer points out, "das antike Denken einen grundlegenden Unterschied zwischen Demokrit und Epikur darin ansetzte, dass dem Atombegriff des Ersteren Züge von Lebendigkeit und Beseelheit zugeschrieben wurden, während Epikurs Theorie mit ihrer Ausgangsbestimmung der Atombewegung als freiem Fall nach unten als Musterbild eines rigiden mechanischen Materialismus galt" (125). However, one 
Augustine seems aware of this difference, when he ascribes to Democritean atoms "a certain animal and vital force" (vim quamndam animalem et spirabilem) which Epicurus' particles do not possess. ${ }^{43}$ A closer look at Democritus' physiology can probably help highlight the influence of hylozoism on early atomism. It will also be more evident why Epicurus needed to fill a gap and provided explanations of the cognitive-psychic life which did not appeal to traditional vitalism, but readapted Aristotelian notions.

According to Democritus, the atoms of soul are largely present in the air. ${ }^{44}$ The soul itself is a material aggregate, composed of a very thin and mobile kind of corpuscles. ${ }^{45}$ While breathing, every living being looses a certain quantity of psychic atoms, and after death (i.e. once the periodical renewal of soul atoms is no more sufficient) all these principles of life disperse. ${ }^{46} \mathrm{On}$ the whole, the cosmos appears as a palpitant mixture of vital entities. Moreover, to a lower degree even the bodily atoms seem to possess some power of sensation, since Democritus maintains that corpses are still endowed with perception. ${ }^{47}$ However, when a body is alive, sensation results from a direct

should always bear in mind that contemporary distinctions between mechanism and vitalism cannot be acritically applied to ancient philosophy: neither Democritus' materialism nor Aristotle's finalism can be easily assimilated to post-Cartesian and post-Darwinian standards, and similar differences should be taken into proper account while studying the Renaissance reception of Graeco-Roman science. See e.g. Casini 1963, 196: "a chi usi con dovuta cautela la definizione di materialismo meccanicistico, applicata ai teorici antichi dell'atomismo dai moderni storici, non accadrà di restare perplesso [...] di fronte al vitalismo moderato di Democrito, e di considerare quest'ultimo un elemento estrinseco giustapposto al suddetto meccanicismo. La fisica degli atomi e la congiunta cosmogonia non entrano necessariamente in conflitto (se non da un punto di vista meccanicistico moderno) con l'idea della genesi dei viventi dalla materia inerte per sviluppo e adattamento spontaneo."

43 See Augustine, Ep. ad Dioscorum (Ep. 118) 28, and the comments of Rechenauer 2009, 125. Macrobius' description of the Democritean soul in Comment. 1.14 .19 (spiritum insertum atomis hac facilitate motus ut corpus illi omne sit pervium) is significantly consistent with Augustine's remarks. In addition, a passage from Cicero's De natura deorum (1.120-121), which is certainly among the sources of Augustine's text (as several striking similarities reveal), depicts Epicurus' extirpation of religious feelings as a more radical attitude than Democritus' allegedly wavering position.

44 See especially Aristotle, De resp. $4.471 \mathrm{~b} 30 \mathrm{ff}$.

45 This aspect of Democritean psychology was clearly assimilated by Epicurus into his system: see Lucretius, $3.177 \mathrm{ff}$. It is also worth mentioning that Democritus never described the soul atoms as igneous (as an old scholarly tradition was inclined to think): qualities such as heat and cold do not belong to the atoms, which differ from each other only on the basis of quantitative conditions (form, size, porosity). As Reichenauer 2009, 119-122 has convincingly shown, the Abderite compared the soul to fire on a secondary physical plane, that of atomic aggregation. Thanks to their round and nimble constitution the soul atoms move in a quick and free way, thus creating very loose bonds: this allows them to arouse cognition and sensation, and such a swift movement originates the macroscopic perception of heat.

46 See the accounts provided by Aristotle, De An. 1.2.404a $10 \mathrm{ff}$.; De resp. $4.471 \mathrm{~b} 30 \mathrm{ff}$.

47 Cf. Aët. 4.4.7; 4.9.20; Alex. Aphrod. In Top. 21.19 ff. Interestingly, Cicero, Tusc. 1.82, refers to Epicurus' objections against this view (Democritum insimulat Epicurus) as well as to the different attitude of Democritus' followers. As an orthodox Epicurean, Lucretius, 3.356-358, 
response of the soul to external impressions. Sensory organs like the eyes

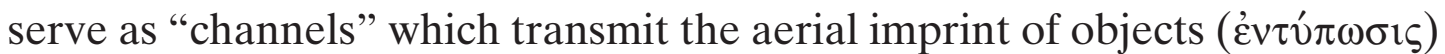
to the psychic atoms; these are diffused through the entire organism and are all involved in the process of perception. ${ }^{48}$ Clearly, a similar model of physiological epistemology presents the soul as a "totalizing" principle. Both the limbs of man and nature as a whole turn out to be permeated by psychic elements, which animate the other parts of matter. By contrast, Epicurus' mechanism seems to have restricted the influence of such hylozoism-oriented assertions, readapting Democritus' atomic psychology into a functional framework.

According to Lucretius and Diogenes of Oenoanda, the Democritean idea of a numerical equality between bodily and psychic atoms is wrong. ${ }^{49}$ The soul's thin particles are present to a lesser extent, but they are able to allow sensory perception because of their swift motion through the limbs. ${ }^{50}$ Diogenes explains this coordinating function of the soul through the image of the rennet used to curdle milk: in the same way as a small quantity of acid juice binds a huge amount of milk, he says, the soul encompasses the whole man. ${ }^{51}$ An analogous view of the body-soul relationship can be found in Lucretius, who compares the body to lumps of incense and the soul to their scent. ${ }^{52}$ Of course, the primary purpose of Lucretius' analogy is to emphasize the connection between psychic and bodily atoms. But the choice of such metaphorical references seems to be no accident: on the one hand, the body

asserts the insensitiveness of corpses (cf. Epicurus, Ep. 2.64). See Reichenauer 2009, 131-132: "Man wird nun ohne weiteres annehmen, dass er (scil. Demokrit) sich die Belebtheit primär an die Seelenatome als die am meisten beweglichen gebunden dachte. Doch wenn selbst nach deren Verflüchtigung Äusserungen der Belebheit im toten Körper zurückbleiben, so ist dies nichts anders zu erklären, als dass auch den übrigen Atomen solche Belebtheit, wenn auch in geringerem Masse, innenwohnt."

48 See the detailed but problematic account of Theophrastus, De sens. 49-58. Theophrastus $(54 ; 57)$ explicitly criticizes Democritus' claim that the whole body (where the soul atoms alternate with properly bodily particles) participates in sensation. Cf. Diano 1974, esp. 146-147. On Democritus' idea of an alternation between soul and body atoms see Alex. Aphrod., De Mixt. $214.18 \mathrm{ff}$.

49 Cf. Lucretius, 3.370-380; Diogenes of Oenoanda, fr. 37 Chilton, coll. 1.2-12. In more general terms, lines 323-414 of Book 3 of De Rerum Natura can be said to form a polemical section aimed at challenging Democritus' psychology from an Epicurean perspective.

50 See especially Lucretius, 3.391-395. It is remarkable that Diogenes, fr. 37 Chilton, coll. 1.5-7, refers his numerical consideration both to the rational and the irrational parts of soul, namely

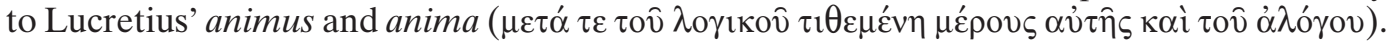
Bailey 1947, 1056, and Ferguson Smith 1993, 487, point out the fundamental similarity between Diogenes' and Lucretius' discussions, while Chilton 1971, 91-92, emphasizes the distance between the two in quite a misleading way.

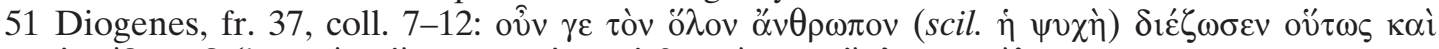

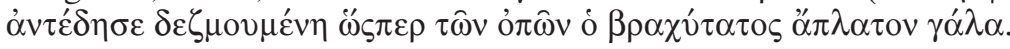

52 See 3.323-336. 
appears as the largest part of the organic compound, while, on the other hand, the soul is presented as a fine and essential content. In the same way as incense is perceived and appreciated on the basis of its scent (even if this is wisp-like), life lies basically in the soul. Notably, in a famous passage of De Anima Aristotle had remarked on the functional unity of body and soul, stating that "we can dismiss as unnecessary the question whether the soul and the body are one", since "it is as though we were to ask whether the wax and its shape are one". ${ }^{3}$

To all appearances, these three analogical patterns have something in common. In all of them the soul is described as a basic principle of organic life, inherent in the body. Furthermore, such a foundational role is explicitly separated from any quantitative prominence, in contrast with Democritus' idea of a numerical and spatial correspondence. Seen in this light, Aristotle's account of psychic functionality stands out as an essential model for Epicurus' thought. When going beyond Democritus' hylozoistic atomism, Epicurus readapted the Aristotelian view of the soul as a factor of functional coordination into his spatial-atomic system..$^{54}$ Just like Aristotle's $\psi v \chi \eta$, the Epicurean soul acts as a core component of animal physiology, but its proper nature is corpuscular rather than purely functional.

In a similar framework, sensory organs like the eyes are no more "channels" aimed to connect psychic atoms and perceptive appearances, as Democritus had previously argued. Lucretius polemicizes vigorously against those who consider the eyes passive "gates" (fores) used by the soul. ${ }^{55}$ He maintains that the body parts are directly involved in sensation, thus denoting a skilful assimilation of the Aristotelian approach..$^{56}$ As is well-known, Aristotle sees perception as both a local and a central phenomenon. And even if considerable scholarly controversy has arisen over the interpretation of Aristotle's epistemology, there can be no doubt that sensation is, in Aristotelian terms, a hylomorphic, systemic process. ${ }^{57}$ In other words, every perceptive experience

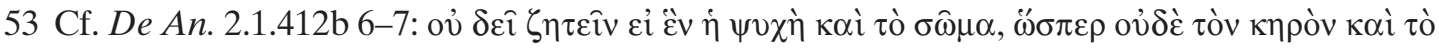
$\sigma \chi \eta \hat{\mu} \alpha$.

54 As Diano 1974, 149, pointed out, in Aristotle "il problema (scil. della sensazione), che già in nисе comprende tutto il problema dello spirito, è necessariamente dialettico e non può essere posto in termini spaziali. In termini spaziali doveva invece porselo Epicuro e [...] egli lo tolse di peso da Aristotele, le cui soluzioni in parte rigettò, in parte accolse secondo lo spirito e le esigenze del suo sistema".

55 Cf. 3.359-369.

56 See esp. 3.350-353.

57 An especially controversial theme is Aristotle's account of the sense organs' alteration. According to Burnyeat 1992, the Stagirite's explanation of perception does not involve any physiological modification of the sensory organs, as these take part in a merely cognitive process. Needless to say, such a thesis objects to the functionalist interpretation of scholars like Sorabji 1974, 1992, and Nussbaum 1978. See also the surveys of Cohen 1992 and Everson 1997. 
is said to concern the specific sense organ engaged as well as the heart, which is the main centre of consciousness. ${ }^{58}$ It is no accident that in the last two passages from De Anima quoted above sensation is ascribed to individual segments of living beings, though for a limited range of time. ${ }^{59}$

Indeed, Epicurus' and Lucretius' depiction of the soul as an all-encompassing entity, which spreads over the entire body but operates locally, seems to be substantially indebted to Aristotle's theory. Didactic arguments such as that of the snake cut off do not necessarily need to be referred to Democritus' heritage, nor to any special atomistic lineage. ${ }^{60}$ A formal model of physiological psychology can be taken on and readapted far beyond the borders of matter theories, so that corpuscularianism and hylomorphism, mechanism and teleology, turn out to work on variously connected planes. As a consequence, similes and images often interact in an unexpected way.

It is now time to switch to the modern age reception of Lucretius' psychology. The snake argument, with its many conceptual and metaphorical implications, will continue to serve as a fil rouge throughout our survey. And in several respects, the choice of focusing on the field of imaginative repre-

58 Cf. e.g. De Part. Anim. 665a 10-15; De An. 3.2.426b 8 ff.

59 De An.1.5.411b 21-22; 2.2.413b 21-24.

60 The malleable character of the argument of dissections is also shown by a passage from Tertullian's De Anima. In De An. 15, the Christian apologist maintains that Asclepiades of Bithynia, the famous physician of the late Roman republic, denied the presence of any hegemonikon in living beings. Asclepiades is said have seen the soul as a merely sensorial and material entity, lacking in any definite rational centre (cf. also Sextus, Adv. math. 7.380). The fact that some animals survive the loss of their head or their heart (where conflicting traditions placed the centre of psychic functions, the so-called hegemonikon) was apparently invoked to confirm such an assertion (Asclepiades etiam illa argumentatione uectatur, quod pleraque animalia ademptis eis partibus corporis, in quibus plurimum existimatur principale consistere, et insuper uiuant aliquatenus et sapiant nihilominus, ut muscae et uespae et lucustae, si capita decideris, ut caprae et testudines et anguillae, si corda detraxeris; itaque principale non esse, quo, si fuisset, amisso cum suis sedibus uigor animae non perseueraret). Indeed, Asclepiades' conception of psychology - as well as his general physical theory have been variously interpreted by scholars (see e.g. the reconstruction of Vallance 1990, and the criticisms of Asmis 1993), since our sources diverge on several points. In a highly problematic passage, for instance, Calcidius, In Timaeum 215, contrasts Asclepiades' idea of the soul with Democritus' and Epicurus' theories. But other texts tend to offer an "atomistic" reading of the Asclepiadean doctrine of ö it may suffice to remark on Asclepiades' readjustment of the dissection argument for the sake of a more radical mechanism. As mentioned above, in fact, Lucretius and his school ascribe to the animus placed in the chest the function of hegemonikon. And Tertullian reasonably includes Epicurus among those who believe in the existence of a psychic centre (sed plures et philosophi aduersus Dicaearchum, Plato Strato Epicurus Democritus Empedocles Socrates Aristoteles, et medici aduersus Andrean et Asclepiaden, Herophilus Erasistratus Diocles Hippocrates et ipse Soranus, iamque omnibus plures Christiani, qui apud Deum de utroque deducimur, et esse principale in anima et certo in corporis recessu consecratum). 
sentations will powerfully contribute to detect differences, affinities, and transformations. ${ }^{61}$

\section{Reshaping the soul. Lucretius and the modern age debate on psychology}

In her careful study of Lucretius' and Epicurus' reception in the Italian Renaissance, Susanna Gambino Longo pointed to the intriguing integration of Epicurean concepts into the physical systems of Aristotelian thinkers. Several scholars of the 16th and 17th centuries seem to have accepted and reshaped Lucretius' doctrines without embracing any consistent atomic theory of matter. According to Gambino Longo, such scholars intended to "correct Aristotle with the help of Lucretius" (since, of course, after its rediscovery De Rerum Natura had become the main source of Epicureanism). ${ }^{62}$ Gambino Longo attempts to show that no substantial contradiction underlies this process of doctrinal assimilation, for Epicurus' criticism of Aristotelian philosophy would only depend on his knowledge of the exoteric works. ${ }^{63}$ However, the idea that the founder of the Garden did not know Aristotle's esoteric corpus has been largely confuted in the last years. It has been persuasively argued that such relevant works as Physics, De caelo and

61 To a certain extent, the approach chosen in the present paper can be compared to the conceptual epidemiology of Sperber 1996a, who regards the progressive transformation of beliefs in different contexts as an especially promising area of inquiry for cultural historians. Notably, Sperber attributes a special significance to the study of animal representations, thus developing a well-known point of Lévi-Strauss' anthropological theory. See, in particular, Sperber $1996 \mathrm{~b}$.

62 Cf. Gambino Longo 2004, esp. 121-177 ("corriger Aristote par Lucrèce" is the meaningful title of a whole chapter). On the cultural influence of Poggio Bracciolini's rediscovery (1417) see now Brown 2010.

63 See Gambino Longo 2004, 136: "Épicure ne connaît de lui (scil. d'Aristote) que ses dialogues et sa proximité avec l'idéalisme platonique. [...] Aussi ne faut-il s'étonner que certaines aristotéliciens du XVI siècle, désireux de fonder une solide théorie de la science aient eu recours à l'épicurisme en tant que chantre de la validité de la connaissance livrée par les sens: la gnoséologie atomiste s'affiche en cela comme une bonne alliée du Stagirite acroamatique. La contradiction n'est donc qu'apparente."

64 See above n. 41. Epicurus' ignorance of the Aristotelian pragmatiai was usually explained on textual grounds, as both Strabo, 13.1.54.608-609, and Plutarch, Sull. 26, refer to the disappearance of Aristotle's library until the late edition of Andronicus (1st century BC). As Moraux 1973, I 93, already observed, however, Andronicus' systematization "nicht als editio princeps des Corpus und nicht einmal aller Lehrschriften angesehen werden kann". In this regard, one should note that Gambino Longo 2004, 136, avoids any improper reference to the problems of textual transmission, stating that "jusqu'à Andronicos de Rodhes, l'Antiquité a connu l'Aristote le plus platonisant, celui du Protreptique et de l'Eudème, ou du De philosophia, les oeuvres d'école étant encore considérées comme trop difficiles et de diffusion limitée". 
De Anima exerted a notable influence on Epicurus' system. ${ }^{64}$ And it is indeed noteworthy that the only survey mentioned by Gambino Longo is Ettore Bignone's problematic book..$^{65}$

In light of the significant connections between Aristotle's and Epicurus' theories highlighted in the first section of this paper, the Renaissance combination of Aristotelian and Epicurean views becomes even more interesting. In a certain sense, the Epicurean efforts to endow earlier atomism with a functional consistency find an echo in the modern age debate. What is more, Lucretius' role in such a long-term intellectual phenomenon seems especially remarkable, as De Rerum Natura devotes special attention to the biological implications of atomic physics, occasionally resorting to Peripatetic-like arguments. ${ }^{66}$ The poem's vivid depiction of corpuscular matter and its relationship to macroscopic evidence offered an attractive model for physiological and epistemological demonstrations, far beyond the limits of orthodox atomism. ${ }^{67}$

In what follows, I shall be dealing with the naturalistic premises of Renaissance psychology in order to highlight Lucretius' influence on Bernardino Telesio, Agostino Doni and Francis Bacon. Such authors are indeed representative of the modern age re-adaptation of Epicurean concepts into non-atomistic systems. ${ }^{68}$ To different degrees (and from different perspectives), they bear witness to the intimate connection between Aristotelianism and Lucretian physicalism in Renaissance science - a connection openly founded on the active reception of ancient texts. Lucretius' psychological exposition could be easily re-arranged into pneumatic or vitalistic frameworks thanks to its underlying functional assumptions. And even if most Renaissance thinkers did not believe in the existence of unchangeable atoms, empty spaces, and merely mechanic processes, they could nonetheless take

65 Bignone 1973.

66 See Schrijvers 1999 and Tutrone 2012a (cf. also above n. 13). Sedley 1998, 166-185, provides an insightful discussion of Theophrastus' influence on De Rerum Natura.

67 See Stückelberger 1972, Meinel 1988, and Johnson/Wilson 2007.

68 While Telesio and Doni clearly reject the idea of a corpuscular discontinuity and apply pneumatic theories, Bacon's relationship to classical atomism is rather controversial. Several studies have maintained his adherence to a properly atomistic philosophy of nature, but other ones have challenged such a view or referred to a "temporary" atomism. A rich bibliographical survey on this matter can be found in Manzo 2001, and Gemelli 1996, esp. 141-195. Gemelli points out Bacon's plastic and speculative use of classical models: "Dal punto di vista empirico l'atomo non ha rivestito alcun ruolo diretto nella sperimentazione baconiana; invece, dal punto di vista speculativo e rappresentativo, esso ha conservato la sua funzione di sempre: l'unità di misura più piccola che consente al pensiero di organizzare l'immaginazione relativa alla complessa architettura della materia. Tale pensabilità mantiene intatto il proprio valore anche in assenza del vuoto oppure in compresenza di una dottrina pneumatica." (195) See also Clericuzio 2000, 75-81, who sets Bacon's position against its contemporary background. 
advantage of Lucretius' materialistic physiology, with its penetrating references to the activities of the psychic substance. ${ }^{69}$

Remarkably, all three of our modern authors appealed to the argument of chopped up animals, trying to connect microscopic and macroscopic phenomena. Their theories had inevitably to cope with religious dilemmas, since in modern age Europe - in Italy and Switzerland as well as in England - any transgression of Christian dogmas for the sake of science could cost very dear. ${ }^{70}$

It is certainly worth expounding the ideas of each author, taking into proper account their specific contexts. I shall begin with Bernardino Telesio's much appreciated treatise De Rerum Natura Iuxta Propria Principia, which echoes Lucretius even in its title. In the fifth book of his work, Telesio maintains that the soul generated from the semen (anima e semine educta), to which he ascribes the most relevant functions of living beings, is spread out over the entire nervous system. He criticizes Aristotle's cardiocentrism as well as the Stagirite's general assumptions on the distribution of the soul. ${ }^{71}$ Clearly, Lucretius' poem is the main source used by the Italian philosopher for his polemic against Aristotle. Telesio seems to take on Lucretius' functional distinction between animus and anima as a satisfactory explanation for the problem of the body-soul relationship. As mentioned at the beginning of this paper, the superior principle of animus is assimilated to divine soul, while the anima diffused through the limbs serves as a paradigm of material psychology. At the same time, it is possible to identify a further rearrangement of Lucretius' dichotomy within the framework of Telesio's physiolo-

69 As mentioned earlier (cf. n. 42), it would be highly misleading to apply post-modern schematizations to the ancient and the Renaissance scientific discussion. As regards Sebastian Basso and the first revivals of atomism, for instance, Gregory 1964, 44-45, rightly noticed that "sarebbe erroneo identificare senz'altro questo atomismo con il meccanicismo, la cui maturazione è invece assai più lenta e complessa della semplice fortuna dell'atomismo democriteo ed epicureo: la concezione corpuscolare della materia rappresenta dapprima l'alternativa che si proponeva alla concezione aristotelica della materia e della forma, dei quattro elementi e delle qualità, una volta eliminata la dottrina delle forme sostanziali [...]. Ciò va detto onde evitare di proiettare alle origini dell'atomismo moderno lo schema assai più recente di una concezione corpuscolare della realtà tutta retta da leggi meccaniche, passibili di trascrizione matematica, schema che troppo spesso ha condizionato anche la valutazione dell'atomismo antico in certa moderna storiografia."

70 In spite of their conciliatory attitudes, both Bacon and Telesio were often regarded as heretics. In 1596, for instance, Clement VIII included several naturalistic works by Telesio into his Index librorum prohibitorum, asking for a proper revision (donec expurgentur, cf. Firpo 1951). Likewise, Mersenne 1625, 217, had not doubt that Bacon's books revealed the heresy of their author ("au reste souvenez vous tousiours en lisant ses oeuvres qu'il est heretique", cf. Gemelli 1996, 101-104). And given his notably radical position, Doni repeatedly incurred religious blame: see De Franco 1973, 15-47.

71 Cf. Telesio 1586, V, 27 (359-367). 
gical discussion. On the one hand, in fact, Telesio's material soul resides primarily in the brain (in cerebro praecipue inhabitare) and directs organic life. But on the other hand, the same kind of soul is inherent in the body parts, where "portions" of psychic substance (animae portiones) carry out local functions. A similar repartition is made possible by the nervous system, though it does not involve any quantitative fragmentation of soul. ${ }^{72}$ Lucretius' idea of a physical and twofold psychology is intentionally deprived of its atomic basis and employed as a functional pattern in order to attack Aristotle from a pneumatic perspective. It is no accident that in the same context Telesio rules out quite decidedly any corpuscular division of the soul. ${ }^{73}$

Interestingly, at the beginning of the chapter dealing with this topic, Telesio's refutation of Aristotelian hylomorphism and cardiocentrism appeals to the argument of cut up animals. The author is aware of the Stagirite's standpoint on such issues, but he suggests interpreting the evidence of dissections in accordance with Lucretius' materialist approach:

Thus, [scil. Aristotle] should have not placed the soul in a single body seat, and if not in the whole body, at least in each flexion. Indeed, he seems to accept such a view in his work On the Motion of Animals,${ }^{74}$ urged by factual evidence, to which he there gets closer. Many animals - especially bloodless animals - show to Aristotle the exactness of a similar assumption. Though cut up into several pieces, these animals seem to live in their single limbs, and they prove to move in the same way as when they were undivided. Aristotle himself explains this fact saying that the origin of motion, namely the motive power of soul, is inherent in each limb. In fact, what he then maintains in strict accordance with his precedent position, viz. that the motive power resides in many parts of living beings, since every animal is formed like a compound of several animals, is greatly absurd and conflicts with his own thesis. [...] And, as I said above, in the case of living and perfect animals different parts prove to move

72 Cf. Telesio 1586, V, 27 (364). The modern philosopher disputes Aristotle's comparison between animals and cities, stating that the Stagirite himself should have drawn different conclusions from his argument. In Telesio's view, it is particularly misleading to see the leading principle of bodies as a static ruler (princeps) and place it in a definite seat, while considering the other districts "exanimate" (exanimes inanesque): neque enim civitatis principisque exemplum id nos admonet, sed in una quidem parte principem animam, et quae decernit et statuit, residere, in reliquis vero, in quibuscumque animae operationes edi videntur, ipsam quidem eadem animam, at quae principi illi civium more pareat eosque edat motus, quos edi decretum illi sit statutumque. Non civibus, imquam, quibus nihil simile habent, conferendae erant corporis partes, sed domibus viisque, quae id civibus praestent, quod animae illae; civibus vero, quae illis proportione respondent animae portiones, diversis positae in locis. Vel e solo igitur animalium motu intelligere licet non corporis universi cordisve formam esse animam nec substantiam omnino in corde, ut in principe sede, residentem, sed aliam a corpore et in cerebro quidem praecipue inhabitare, sed nervoso generi universo inexsistere.

73 Cf. Telesio 1586, V, 27 (363-364): in animalibus vero quae inest anima, nihil vere a se ipsa separata divisaque, sed maxime sibi ipsi continua maximeque unita et una omnino, at quae tamen, quod diversis inexsistit partibus, in multa divisa et ipsa videri possit.

74 Cf. Aristotle, De Motu Animalium 702b 17-19. 
singly and separately from each other: so, it is unquestionable that the motive power of soul, or rather the soul itself, is located in each limb. ${ }^{75}$

The snake argument of De Rerum Natura, which resumed and readjusted an Aristotelian theme, lays the foundations of Telesio's polemic. As is wellknown, however, the Italian philosopher conceived of the soul as a continuous substance under the influence of Stoic pneumatic views. ${ }^{76}$ In more general terms, his philosophy of nature was based on traditional qualitative principles such as heat and cold, which he integrated into a mostly immanent physiology. ${ }^{77}$ The only exception to such a daring immanentism was Telesio's idea of a second immortal soul, infused by God into human beings ( $a$ Deo immissa). This was presented in Aristotelian terms as the form of the body and of the material soul (forma corporis et praecipue spiritus). ${ }^{78}$ Nevertheless, passages like the one just quoted reveal Telesio's dependence on Epicurean psychology and its biological arguments. ${ }^{79}$

75 Telesio 1586, V, 27 (359-360): neque igitur uno in corporis loco animam ponendam esse, et si non in universo corpore, in singulis saltem flexibus. Id quod in De animalium incessu a re ipse, ut videtur, quam scilicet proximius ibi attingit, tandem admonitus facere videtur; et quod faciendum omnino esse, animalia multa, exsanguia praesertim, Aristoteli item declarant, quae, in partes multas incisa, singulis diu vivere et singulis moveri videntur iisdemque prorsus motibus, quibus integra movebantur. Vel ipsi enim Aristoteli propterea id fieri videtur, quod principium, hoc est motiva animae vis, singulis illis insit. Nam, quod positionis tenax subdit, propterea multis eorum in partibus motivum inesse principium, quod illorum quodque perinde constitutum sit, ac si quippiam ex animalibus multis compositum sit, et perabsurdum est et contra proprium etiam dogma. [...] Et in viventibus, ut dictum est, perfectissimisque animalibus partes per se singulae seorsumque ab aliis moveri videntur: ut dubitare non liceat motivam animae vim, quin animam ipsam, singulis inexsistere. Here and elsewhere, the English translation of modern age Latin texts is mine.

76 On Telesio's relationship to Stoic psychology see e.g. Skrbina 2005, 69-70: “Telesio, like Cardano, was strongly influenced by Stoicism. His distinction between active (heat and cold) and passive (matter) is one example. More important was his conception of soul, which has many similarities to the Stoic pneuma. Both entities were seen as corporeal, each existing as a substance of extreme tenuity and subtlety. Soul, like the pneuma, pervaded all things. And like pneuma, it is the embodiment of the active principles."

77 Admittedly, the Telesian view of nature and the cosmos is indebted to both Aristotle and the Stoics. In fact, even if Telesio criticizes Peripatetic physics from several points of view, his interpretation of matter and natural processes still draws on Aristotle. Cf. Schuhmann 2004, 100: "There are, Telesio holds, three principles of natural things: heat, cold and matter; and this trinity he opposes to the threefold Aristotelian opposition of form, privation and matter. In Telesio heat and cold can be paralleled to form, and privation is completely rejected, so it is only Aristotle's matter which survives unharmed. This could have to do in part with Telesio's reception of Stoic doctrine. For it is in agreement with the Stoics that he sees matter not only as a principle of individual bodies, but as the unique substrate of the world as a whole. Yet Telesio's argument for the necessity of positing matter clearly owes something to Aristotle also."

78 See Telesio 1586, V, 3 (214-216). There has been much scholarly discussion about the role of Telesio's immortal soul. On the basis of its marginal importance, several studies inclined to describe such an additional metaphysical principle as a mere concession to the Church. See Pupo 1999.

79 Other noticeable analogies between Telesio's and Lucretius' psychology are discussed in Gemelli 1996, 104 ff. Kessler 1992 devotes special attention to the impact of Epicurean anti-providentialism on Telesian thought. 
An analogous readaptation of Lucretian patterns emerges from Agostino Doni's treatise De Natura Hominis, published in Basel in $1581 .{ }^{80}$ This audacious "heretical" physician embraced Lucretius' materialist tenets to a greater extent than Telesio. ${ }^{81}$ In particular, his psychological theory concentrated on one kind of soul, a continuous material spiritus performing complex processes such as imagination, reason and memory. ${ }^{82}$ Although Telesio's immortal soul was generally excluded from direct physiological explanations, the famous philosopher tried to connect its presence to the origin of human rationality ${ }^{83} \mathrm{By}$ contrast, Doni went so far as to ascribe to the material soul the logical faculties, which were traditionally reputed to mirror man's divine essence. ${ }^{84}$ References to metaphysical principles are almost completely absent from Doni's work, since the final peroration of De Natura Hominis, which touches upon the problem of immortality for apologetic purposes, sounds like a skin-deep and precautionary addition. ${ }^{85}$ However, the author shared Telesio's Stoic-influenced pneumatism and described the soul in terms of tension and concord, largely drawing on Seneca's Naturales Quaestiones. ${ }^{86}$ Doni also presents the soul as a continuous substance (una numero tota continua substantia), which is nonetheless divisible (partibilis) and inherent in the body parts. ${ }^{87}$ Thus, as in the case of Telesio's psychology, the Epicurean concept of functional repartition is re-adapted to a pneumatic-vitalistic system.

80 The most complete presentation of Doni's life and work is De Franco 1973. Unfortunately, we know very little about the biography of this doctor-philosopher, born in Cosenza and fled to Switzerland in order to escape religious persecution. However, his physiological theories are highly interesting, also because they denote a critical use of ancient sources (see De Franco 1973, 48-87).

81 Doni is often mentioned as a pupil of Telesio (see e.g. Bacon 1623b, 348), and he does echo the thought of his major compatriot in several respects. At the same time, one should bear in mind that Doni published De Natura Hominis five years before Telesio's last edition (1586). And it is noteworthy that the first two versions of De Rerum Natura Iuxta Propria Principia (1565 and 1570) did not include any specific treatment of human nature. Cf. De Mas 1962, 380, De Franco 1973, 133-190, and Gemelli 1996, 104.

82 See Doni 1581, II, 11 (346-349).

83 See e.g. Telesio 1586, V, 40 (446-448), where the reasoning power of divine soul is said to act through the functions of physical soul (spiritus ope ac ministerio opus habet). Similarly, in VIII, 15 (232), reason is depicted as a common function of the two kinds of soul.

84 A case in point is, of course, Aristotle's discussion of human intellect (vov̂s): cf. above nn. 36-37.

85 De Franco 1973, 186, has suitably defined the concluding Peroratio as a "pass" for Doni's theories: "La chiusa dell'opera, tutta ispirata com'è ad idee religiose, dovrebbe poter costituire come un lasciapassare per queste sue teorie; e perciò, anche se incongruente ed in disaccordo con tutto il resto dell'opera, non si può dire che sia un appiccicaticcio involontario."

86 See especially Doni 1581, II, 15 (382): toto corpore a nulla parte spiritus fieri motum aliquem (scil. censeo statuendum), qui a capite non intendatur et quod inde omnino per intentionem non capiatur; sicut inde ad omnes partes est conspiratio et continuatio et intentio omnino in omnes. Cf. Seneca, Nat. 2.6, and the remarks of Gemelli 1996, 111.

87 Doni 1581, II, 15 (380). 
From the perspective of the present survey, a scientific issue of special interest is Doni's idea of spiritus caput, the so-called "head of soul". According to the author, even if the entire body is imbued with the soul (spiritus), and this cannot be fragmented into particles, ${ }^{88}$ a relevant part of psychic substance located in the brain (sub cava cerebri) plays a leading role comparable to that of Lucretius' animus. Such an outstanding component is called spiritus caput, and in order to depict its relationship to the other parts of soul, Doni cites the case of cut up animals:

Definitely, the head of soul is the quantity of psychic substance located in the brain cavity, as I remember I said before. And the fact that the heart of many animals seems to continue its motion by itself, after it has been pulled out, does not contradict such a view; as I said, in fact, all the parts of soul possess the principle of motion; and it suffices to transmit once the motion stimulus $^{89}$ in order to allow such parts to go on for a while, until they maintain a certain level of forces. However, the heart pulled out moves irregularly and confusedly, and more and more slowly, as it loses its force little by little and dies. Of course, if a similar argument were of some value, the head of soul could also be placed in the snakes' tail, since this continues to move for a sufficiently long time, after it has been cut off. ${ }^{90}$

Lucretius' idea of a functional bipartition is wisely re-used in order to account for the soul's distribution. While the Epicurean animus resided in the middle of the chest and was made up of atoms, Doni's "head of soul" lies in the brain and is a definite quantity (copia) of continuous substance. However, in the same way as Lucretius' animus supervised the anima, Doni's spiritus caput directs the other parts of soul spread out through the limbs. ${ }^{91}$ Notably, it is the spiritus caput that gives rise to local motion, ${ }^{92}$ and the evidence drawn

88 Doni's rejection of any corpuscular view of matter emerges most conspicuously from II, 2 (310-313), where it is made clear that nature's primary elements are earth (terra) and ether (aether), secondarily originating common bodies. Consequently, Epicurus' atomism is included into a list of erroneous theories: qua quidem ratione statuenti tibi non erit verendum ne vel Empedoclis concors conventus elementorum, alioqui immutabilium sed in minutissima redactorum, ut refert Aristoteles, vel Epicuri atomorum concursus, aut Anaxagorae homeomeria, aliaeve eiusmodi ineptiae obijciantur.

89 The Latin verb employed to describe this kind of impulse transmission (intendi) entails a reference to the "tensive", Stoic-like conception of soul mentioned above (cf. n. 85). And the same can be said of the expression virium tenor.

90 Doni 1581, II, 15 (382): est autem caput definite ea copia quae est sub cava cerebri, sicut memini antea a me esse dictum. Neque obsit quia multorum animalium cor abscissum videtur adhuc posse persequi per se motum; omnes enim spiritus partes, ut dixi, principium habent motus; et satis est intendi illis semel motum, deinde per se etiam parumper persequi possunt dum virium tenorem habent aliquem. Sed cor abscissum incondite tamen turbateque movet et usque languidius, ut vim amittit in momenta et commoritur. Certe, si ea caussa valeat, in cauda etiam serpentum caput spiritus poni possit, quia detruncata satis diu adhuc moveatur.

91 In 3.136-139, Lucretius himself compared the animus to a sort of "head" (caput) dominating over the body: "nunc animum atque animam dico coniuncta teneri/ inter se atque unam naturam conficere ex se,/ sed caput esse quasi et dominari in corpore toto/ consilium, quod nos animum mentemque vocamus."

92 Cf. Doni 1581, II, 15 (380): “capitis enim illud est munus: nempe, ut ab eo omnis incipiat et ad id omnis referatur motus, sitque quasi cardo aut verius moderamen motuum omnium, qui fiunt tota universitate, cuius id est caput." 
from animal life is used to demonstrate the presence of a motion principle in any body part. On the one hand, of course, a similar contention recalls Aristotle's De Anima and its qualitative, anti-atomistic approach. But on the other hand, Doni's belief in a material repartition of the soul founded on two basic poles differs substantially from hylomorphism and resembles Epicurean psychology. ${ }^{93}$ Above all, the mention of snakes seems to allude explicitly to the didactic imagery of De Rerum Natura.

A much more well-known example of Renaissance physiological eclecticism is Francis Bacon. In his works, Bacon repeatedly cites the fact that some animals move after being dissected. Similar scientific arguments appear to combine such ancient accounts as those of Lucretius and Tertullian ${ }^{94}$ with modern discussions - and possibly with personal experiences. ${ }^{95}$ Special attention should be paid to Bacon's careful integration of different classical models. The Baconian theory of matter is deeply influenced by both pneumatic and alchemic concepts, and its models include Greek and Latin texts as well as medieval traditions. ${ }^{96}$ It is indeed remarkable that while Bacon never adopted an orthodox atomic theory (that is, a theory exclusively based on atoms and void), he made frequent use of originally atomistic paradigms. ${ }^{97}$ In the philosopher's eyes, classical corpuscularianism stood out for its strong inclination to empirical observation, but its underlying cosmology seemed in need of consistent revisions. As Graham Rees pointed out, Bacon devised a wide-ranging system of "speculative philosophy" - usually neglected by

93 Like Telesio, Doni refutes the Aristotelian image of different animals composing one living being: see II, 15 (380): sed si (scil. spiritus) qualibet sui parte habet principium motus et quavis potest quemvis capere motum, plane poterit etiam pluribus partibus alios atque alios auspicari motus. Neque propterea plura esse spiritus capita debet existimari; nam plures spiritus et plura animalia sint oportet ut plura sint capita: unius animalis unus spiritus, et unius spiritus unum caput est.

94 On Tertullian's exposition of Asclepiades' theories see above n. 60.

95 In Bacon 1623a, 477, for instance, the classical example of snakes, insects and other animals is compared with the evidence offered by contemporary executions. The philosopher recalls the bloody execution of a traitor, whose heart bounced more and more slowly in the fire: anguillae, serpentes, et insecta diu moventur singulis partibus post concisionem; ut etiam rustici putent partes singulas ad se rursus uniendum expedire. Etiam aves capitibus avulsis ad tempus subsultant: quin et corda animalium avulsa diu palpitant. Equidem meminimus ipsi vidisse hominis cor, qui evisceratus erat (supplicii genere apud nos versus proditores recepto), quod in ignem de more injectum saltabat in altum, primo ad sesquipedem, et deinde gradatim ad minus; durante spatio, ut meminibus, septem aut octo minutarum. Etiam vetus et fide digna traditio est, de bove sub eviscerationem mugiente. At magis certa de homine, qui eo supplicii genere (quod diximus) evisceratus, postquam cor avulsum penitus esset, et in carnificis manu, tria aut quattuor verba precum auditus est proferre [...].

96 See the fundamental analyses of Rees 1975a, 1975b,1977,1980 and 1984. Very useful insights can also be found in Fattori 1984 and Gaukroger 2001, who refer, among other things, to the role of Paracelsian ideas.

97 Cf. Rees 1980 and Gemelli 1996, 141-195. See also above n. 68. 
scholars - which was intended to account for the whole of natural reality. ${ }^{98}$ And in this comprehensive system Lucretius' atomic arguments merged with pneumatic principles, Aristotelian qualities, and Paracelsian beliefs. Bacon's psychology offers a particularly interesting field of inquiry. Although the author did not conceived of the soul in properly corpuscular terms, he used Lucretius' functional distinction between two psychic principles for three main purposes. First and foremost, like Telesio, Bacon separated the idea of a material spirit from that of a divine, immortal soul. In his treatise $D e$ Dignitate et Augmentis Scientiarum, he emphasized the difference between the former kind of soul (Anima Sensibilis sive Producta or Spiritus), common to all animals, and the latter (Anima Rationalis), which he presented as the source of human reason as well as the product of God's breath (a Spiraculo Dei). ${ }^{99}$ No doubt, Telesio's views exerted a profound influence on Bacon, but such views blended inextricably into the heritage of ancient thought. ${ }^{100}$ When resuming concepts and images of classical psychology, both authors were careful in avoiding overt clashes with Christian theology and focused deliberately on the nature of the material soul. ${ }^{101}$

98 Cf. e.g. Rees 1984, 267-268: "The speculative philosophy was not the philosophy for which Bacon became famous. As everybody knows, his reputation rests on the ambitious method and programme which aimed to supplant existing systems of natural philosophy with new sciences generated by applying inductive procedures to colossal bodies of scrupulously verified empirical and experimental data. [...] All that is well-known, but it is only one dimension of Bacon's work. In recent years it has become apparent that he devoted considerable effort to another, quite different end. Not only did he develop the method and programme; he also developed a speculative system of positive natural philosophy. This speculative philosophy is not a set of recommendations for rebuilding the sciences but a comprehensive system of explanations of natural phenomena, a system that sought to account for the structure, substance and motion of the heavens, for the motions of the winds and tides, the transformations of inorganic bodies, plant and animal physiology, and animal psychology and pathology. In short, Bacon attempted to produce an explanatory system quite as comprehensive as those of Aristotle and Descartes."

99 See Bacon 1623b, 344-348.

100 In Bacon 1623b, 348, Telesio and Doni are explicitly recalled for their valuable contributions to the study of psychology: "[...] quemadmodum Bernardinus Telesius, et discipulus ejus Augustinus Donius, aliqua ex parte non omnino inutiliter asseruerunt.” On Bacon's repeated mentions of Telesio and their philosophical significance see Giachetti Assenza 1980 and Bondì 2001. Notably, the idea that Doni was a disciple of Telesio, credited here by Bacon himself, has been challenged by De Franco 1973, 165. For a careful comparison between the psychological theories of Bacon, Doni and Telesio see Gemelli 1996, 99-139.

101 Cf. Walker 1984, 224: "The traditional medical theory that animal spirits perform, or are the first instrument of the soul in performing, such psychic functions as appetite, common sense and imagination, that men have in common with animals, tends to confine the function of the incorporeal soul to abstract reasoning, that which differentiates men from animals. Those who followed this path, such as Telesio, Francis Bacon and Descartes, may have intended to preserve both the normal metaphysical division between mind and matter and the orthodox Christian doctrine of an incorporeal and immortal soul. But by accepting that spirits alone could perform the lower two functions of the Aristotelian tripartite soul, i.e. the vegetative and sentient, they were moving in dangerous direction, namely, towards a position where the soul is identified with the spirit." 
It is in his discussion of the physical spiritus that Bacon deployed a second readaptation of Lucretius' psychological division, as he argued for the existence of two subkinds of spiritus: the so-called spiritus mortuales, which can also be found in inanimate beings and are discontinuously distributed, and the spiritus vitalis, which pervades living beings in a continuous way. ${ }^{102}$ A similar bipartition is directly connected with Bacon's "speculative philosophy", since, on the whole, the spiritus is described as a compound of air (aër) and fire (flamma), varying according to the relevance of such components. The spiritus mortuales are more air-like, while the swiftness of the spiritus vitalis resembles the nature of a flame. ${ }^{103}$ From a cosmological point of view, the spiritus belongs to the class of pneumatica, one of the two basic constituents of sublunary world, the other one being tangibilia, tangible bodies. ${ }^{104}$ In the Historia Vitae et Mortis, which deals at length with psychological matters, Bacon states that tangibilia, namely common objects, do not contain any empty space, for they are imbued with either spiritus or air. ${ }^{105}$

Clearly, Bacon's cosmological and psychological thought creatively manipulates Lucretius' teachings. To begin with, even if void is not included in the constitution of things, the general quantity of matter is said to remain constant through all its changes - a basic theme of Lucretius' first book. ${ }^{106}$ Most important, Bacon's idea of a material soul has an undeniably Lucretian flavour. The "aerial" and "flaming" character of the Baconian spiritus owes much to Lucretius' doctrine of the soul's four "natures" (naturae), purposely deprived of its atomic basis. ${ }^{107}$ Likewise, the spiritus mortuales and the spi-

102 See Bacon 1623a, 485-488.

103 Indeed, Bacon does not incline to distinguish his two types of spiritus in terms of material composition sensu proprio. In Bacon 1623a, 487-488, he argues against the idea that air and fire can actually be mixed and refers to a sort of "analogical" intepretation (quod vero dicitur in canone, quod spiritus vitales magis accedant ad substantiam flammae; illud intellegendum est, quod magis hoc faciant quam spiritus mortuales; non quod magis sint flammei quam aërei). Nevertheless, the author's ambiguity in this regard has inevitably led scholars to speak in terms of "compounds": see e.g. Rees 1984, 268-270.

104 Cf. Fattori 1984, 290-291: "Dans le monde sublunare il existe deux types de corps, les tangibilia et les pneumatica: et ces derniers (les pneumatica) sont - ecrit Bacon - de trois types: inchoata, devincta, pura. L'Historia Vitae et Mortis, qui s'occupe de tous le corps du monde sublunaire, traite du second type de corps pneumatiques, les pneumatica devincta." As Bacon makes clear, pneumatica devincta is the scientific name for spiritus. See Bacon 1658, 46: at pneumatica devincta ea sunt, quae ipsa solitaria aut soluta non reperiuntur, sed tantum corporibus tangibilibus inclusa; quos spiritus etiam vulgo vocant.

105 Bacon 1623a, 483-484: nullum corpus nobis notum, hic in superiore parte terrae, spiritu vacat; sive per attenuationem et concoctionem caloris coelestium, sive alias. Neque enim cava rerum tangibilium vacuum recipiunt; sed aut aërem, aut spiritum rei proprium.

106 See Bacon 1623a, 483 (nullum est rerum interitus: itaque quod absumitur, aut evolat in aërem aut recipitur in corpus aliquod adjacens), and Lucretius 1.215-264.

107 Cf. Lucretius, 3.231-306 (and the mention of heat and air in 3.117-129). It is very likely that Bacon took up Lucretius' theories through the filter of Doni's reflection. See Gemelli 1996, 130-133. 
ritus vitalis are said to originate a sort of "consent", that is to say a functional interaction, which is reminiscent of Lucretius' view of the body-soul relationship. ${ }^{108}$ The spiritus vitalis superintends the activities of the other spiritus in the same way as the Epicurean animus supervised the anima. ${ }^{109}$ And though inherent in each body part and organ, local functions are said to be allowed by the spiritus vitalis. ${ }^{110}$

A third echo of Lucretius' psychological dichotomy can be perceived in Bacon's subdivision of the spiritus vitalis into two main forms: the spiritus ramosus, which permeates the body through various branches, and the spiritus cellulatus, which is a major concentration of psychic substance residing in the brain. Plants are only endowed with the spiritus ramosus, whereas in animals this kind of spirit descends from a leading agglomeration placed in the cerebral ventricles. ${ }^{111}$ While explaining his theory (which clearly echoes Telesio's and Doni's ideas), Bacon cites the case of chopped up animals:

And this spirit (scil. the spiritus vitalis) is also twofold; the first kind of it is just branched, as it permeates the body through little channels and ducts similar to lines; by contrast, the second kind has also a seat, so not only is it continuous, but it also assembles in a hollow space, in a rather large quantity, and in analogy with the body; moreover, the source of the streamlines gushing out is in that cell. Such a cell resides primarily in the brain ventricles, which in lower animals are narrow; so the spirits seem to be diffused through the whole body rather than assembled in a cell: as it is possible to observe in snakes, eels and flies, whose pieces move at length after being cut off; birds also wince at length once their heads have been pulled out; since they have small heads, and small cells; but higher animals have larger ventricles; and man more than any other being. ${ }^{112}$

108 Bacon 1623a, 486: "At spiritus vitalis, tametsi eos (scil. spiritus mortuales) regat, et quendam habeat cum illis consensum, longe alius est ab ipsis; integralis et per se constans." Cf. Lucretius, 3.168-169: "Praeterea pariter fungi cum corpore et una/ consentire animum nobis in corpore cernis."

109 See the text in the preceding note.

110 See Bacon 1623a, 487: “Actiones sive functiones quae sunt in singulis membris naturam ipsorum elementorum sequuntur (attractio, retentio, digestio, assimilatio, separatio, excretio, perspiratio, etiam sensus ipse); pro proprietate organorum singulorum (stomachi, jecoris, cordis, splenis, fellis, cerebri, oculi, auris, et ceterorum). Neque tamen ulla ex ipsis actionibus unquam actuata foret, nisi ex vigore et praesentia spiritus vitalis et caloris eius [...]."

111 Cf. also Bacon 1627, 431: "The affinities and differences between plants and living creatures are these that follow. They have both of them spirits continued, and branched, and also inflamed. But first, in living creatures the spirits have a cell or seat, which plants have not; as was also formerly said. And secondly, the spirits of living creatures hold more of flame than the spirits of plants do. And these two are the radical differences."

112 Bacon 1623a, 486-487: “Atque hic spiritus (scil. spiritus vitalis) etiam duplex est; alter ramosus tantum, permeans per parvos ductus et tanquam lineas; alter habet etiam cellam, ut non tantum sibi continuetur, sed etiam congregetur in spatio aliquo cavo, in bene magna quantitate, pro analogia corporis; atque in illa cella est fons rivolorum, qui inde diducantur. Ea cella praecipue est in ventriculis cerebri, qui in animalibus magis ignobilibus angusti sunt; adeo ut videantur spiritus per universum corpus fusi, potius quam cellulati: ut cernere est in serpentibus, anguillis, muscis, quorum singulae portiones abscissae moventur diu: etiam aves diutius capitibus avulsis subsultant; quoniam parva habeant capita, et parvas cellas; at animalia nobiliora ventriculos eos habent ampliores; et maxime omnium homo." 
Since the author's scientific background includes both ancient and modern sources, the physiological insights of Lucretius (as well as those of Aristotle and Tertullian) are reinterpreted in light of contemporary debates. ${ }^{113}$ One of the most intriguing aspects of the passage concerns the harmonization of classical arguments with the author's own natural philosophy. The narrowness of cerebral ventricles, for instance, is presented as the fundamental reason for post-mortem movements, and the whole analysis rests on the Baconian contrast between spiritus cellulatus and spiritus ramosus. Once again, Lucretius' functional distinction seems to provide an easily adaptable basis for material psychology, far beyond its original atomistic implications.

Like Telesio and Doni, Bacon gives up Lucretius' view of the chest as the centre of psychic life and emphasizes the role of the nervous system. ${ }^{114}$ Nonetheless, the Epicurean notions of animus and anima continue to serve as conceptual patterns to represent the relationship between central and peripheral nervous system. What is more, Lucretius' idea of a bifocal interaction is used to clarify the problem of the spirit's adherence to the limbs a modern outgrowth of the ancient debate on the body-soul relationship.

Among the several ideological shifts occurred in the transition from Lucretius' poem to its modern receptions, one of great interest regards the attitude towards the status of animals. In the first section of this paper, we had a chance to remark on Lucretius' intentional assimilation of human and animal physiology as well on its ethical-didactic aims. By contrast, Bacon's observations on the natural superiority of human beings denote a deeprooted anthropocentric outlook which is admittedly central to the author's worldview. ${ }^{115}$ After all, the imaginative richness of Lucretius' disturbingly antiprovidential work allowed Renaissance readers to undertake a pur-

113 In this respect, it may be worth noticing that in his Philosophiae naturalis adversus Aristotelem libri XII (1621), Sebastian Basso (who is often celebrated as one of the pioneers of Renaissance atomism) appeals to the snake argument in order to demonstrate the divisible nature of vegetative soul. As Gemelli 1996, 107, pointed out, Basso's text resembles Lucretius' treatment in spite of its basic commitment to the Platonic tradition.

114 As is well-known, the debate on the function of the brain and the nervous system dates back to classical antiquity: see e. g. the stimulating reconstructions of Crivellato/Ribatti 2007, Lo Presti 2008, and Frampton 2008.

115 As Merchant 2006, 518, pointed out, “Bacon's goal was to use constraint and force to extract truths from nature. His choice of words was part of a larger project to create a new method that would allow humanity to control and dominate the natural world". This essential aspect of the Baconian Weltanschauung is extensively dealt with in Merchant 1980, a much discussed but penetrating book. However, it should also be noted that Bacon's repeated references to the evidence of dissections entail occasional variations. In Bacon 1627, 352-353, for example, the width of cerebral ventricles is said to characterize both men and "beasts", i.e. higher animals, in contrast with lower animals such as birds. Moreover, in the same context the philosopher cites the case of a human eye, which was successfully replaced after being extracted. 
poseful selection - for in an age of contrasts, changes and religious torments, the masterpiece of Epicurean materialism was bound to be dismembered like a snake's body.

\section{Bibliography}

\section{Sources}

[In this article works of modern age authors are quoted referring to the selected edition. In the case of Telesio and Doni page numbers appear in brackets after the reference to book and paragraph; in the case of Bacon page numbers only are given].

Bacon 1611-19 = Bacon, Francis, Philosophical Studies, c. 1611-c.1619, ed. Graham Rees (Oxford 1996)

Bacon 1623a = Bacon, Francis, Historia Vitae et Mortis. Sive Titulus Secundus in Historia Naturali et Experimentali ad condendam Philosophiam: Quae est Instaurationis Magnae Part Tertia, in: Spedding, James/Ellis, Robert Lesley/Heath, Douglas Denon (eds), The Works of Francis Bacon, Baron of Verulam, Viscount St. Albans, and Lord High Chancellor of England (New York/Boston 1864), stereotyped and printed by H. O. Houghton, III 327-502

Bacon 1623b = Bacon, Francis, De Dignitate et Augmentis Scientiarum, in: Spedding, James/Ellis, Robert Lesley/Heath, Douglas Denon (eds), The Works of Francis Bacon, Baron of Verulam, Viscount St. Albans, and Lord High Chancellor of England (Boston 1864), stereotyped and printed by H. O. Houghton, II 97-498

Bacon 1627 = Bacon, Francis, Sylva Sylvarum, or a Natura History. In Ten Centuries, published after the Author's death by W. Rawley, in: Spedding, James/ Ellis, Robert Lesley/ Heath, Douglas Denon (eds), The Works of Francis Bacon, Baron of Verulam, Viscount St. Albans, and Lord High Chancellor of England (Boston 1864), stereotyped and printed by H. O. Houghton, IV 151-477

Bacon 1658 = Bacon, Francis, Historia Densi et Rari in: Spedding, James/ Ellis, Robert Lesley/Heath, Douglas Denon (eds), The Works of Francis Bacon, Baron of Verulam, Viscount St. Albans, and Lord High Chancellor of England (New York/ Boston 1864), stereotyped and printed by H. O. Houghton, IV, 27-118

Doni 1581 = Doni, Agostino, De Natura Hominis, in: De Franco, Luigi, L'eretico Agostino Doni medico e filosofo cosentino del '500, Appendice (Cosenza 1973)

Lucretius DRN 1969 = T. Lucretius Carus, De Rerum Natura Libri Sex, ed. Martin, Joseph (Leipzig 1969)

Mersenne 1625 = Mersenne, Marin, La Vérité des Sciences. Contre les Septiques ou Pyrrhoniens (Faksimile-Neudruck der Ausgabe Paris, 1625, Stuttgart/Bad Cannstatt 1969)

Telesio 1586 = Telesio, Bernardino, De rerum natura iuxta propria principia, ed. De Franco, Luigi (Cosenza 1974)

\section{Studies}

Asmis, Elizabeth, Epicurus' Scientific Method (Ithaca/London 1984)

Asmis, Elizabeth, “Asclepiades of Bithynia rediscovered?”, Classical Philology 88/2 (1993) 145-156 
Barnes, Jonathan (ed.), The Complete Works of Aristotle, 2 vols. (Princeton, NJ 21985)

Bignone, Ettore, L'Aristotele perduto e la formazione filosofica di Epicuro, 2 vol., (Florence 1936, repr. 1973)

Bondì, Roberto, «Bacone e la restaurazione di Parmenide», Rivista di Filosofia 92 n. 2 (2001) 327-340

Brown, Alison, The Return of Lucretius to Renaissance Florence (Cambridge, MA/ London 2010)

Burnyeat, Myles, "Is an Aristotelian Philosophy of Mind Still Credible? (A Draft)", in: Martha C. Nussbaum/Amélie Oksenberg Rorty (eds), Essays on Aristotle's De Anima (Oxford 1992) 15-26

Casini, Paolo, «Zoogonia e trasformismo nella fisica epicurea», Giornale Critico della Filosofia Italiana 42 (1963) 178-207

Chilton, Cecil William (ed.), Diogenes of Oenoanda, The Fragments (Oxford 1971)

Clericuzio, Antonio, «Spiritus Vitalis. Studio sulle teorie fisiologiche da Ferner a Boyle», Nouvelles de la République des Lettres 2 (1988) 33-84

Clericuzio, Antonio, Elements, Principles and Corpuscules. A Study of Atomism and Chemistry in the $17^{\text {th }}$ Century (Dordrecht 2000)

Cohen, S. Marc, "Hylomorphism and Functionalism", in: Martha C. Nussbaum/Amélie Oksenberg Rorty (eds), Essays on Aristotle's De Anima (Oxford 1992) 57-73

Crivellato, Enrico/Ribatti, Domenico, "Soul, Mind, Brain: Greek Philosophy and the Birth of Neuroscience", Brain Research Bulletin 71, 4, (2007) 327-336

De Franco, Luigi, L'eretico Agostino Doni medico e filosofo cosentino del '500 (Cosenza 1973)

De Mas, Enrico, «La dottrina dell'anima umana e delle sue facoltà nel sistema di F. Bacone», Filosofia 13 (1962) 371-408

Diano, Carlo, «La psicologia d'Epicuro e la teoria delle passioni», in: Carlo Diano, Scritti epicurei (Florence 1974) 129-280

Dionigi, Ivano, Lucrezio: Le parole e le cose (Bologna 1988)

Dionigi, Ivano, "Lucretius, or the Grammar of the Cosmos", in: Marco Beretta/Francesco Citti (eds), Lucrezio, la natura e la scienza (Florence 2008) 27-34

Everson, Stephen, Aristotle on Perception (Oxford 1997)

Fattori, Marta, «Spiritus dans l'Historia Vitae et Mortis de Francis Bacon», in: Marta Fattori/Massimo Luigi Bianchi (eds), Spiritus. IV Colloquio Internazionale del Lessico Intellettuale Europeo (Roma, 7-9 gennaio 1983) (Rome 1984) 283-323

Ferguson Smith, Martin (ed.), Diogenes of Oinoanda, The Epicurean Inscription (Naples 1993)

Firpo, Luigi, «Filosofia italiana e Controriforma. IV: La proibizione di Telesio», Rivista di Filosofia 42 (1951) 30-47

Frampton, Michael, Embodiments of Will: Anatomical and Physiological Theories of Voluntary Animal Motion from Greek Antiquity to the Latin Middle Ages, 400 B.C.A.D. 1300 (Saarbrücken 2008)

Furley, David J., "Lucretius and the Stoics", Bulletin of the Institute of Classical Studies of the University of London 13 (1966) 13-33

Furley, David J., Cosmic Problems. Essays on Greek and Roman Philosophy of Nature (Cambridge 1989)

Gambino Longo, Susanna, Savoir de la nature et poésie des choses: Lucrèce et Épicure à la Renaissance italienne (Paris 2004) 
Garani, Myrto, Empedocles Redivivus: Poetry and Analogy in Lucretius (New York/ Abingdon 2007)

Gaukroger, Stephen, Francis Bacon and the Transformation of Early-Modern Philosophy (Cambridge 2001)

Gemelli, Benedino, Aspetti dell'atomismo classico nella filosofia di Francis Bacon e nel Seicento (Florence 1996)

Giachetti Assenza, Valeria, «Bernardino Telesio: il migliore dei moderni. I riferimenti a Telesio negli scritti di Francesco Bacone», Rivista Critica di Storia della Filosofia 35 (1980) 41-78

Gigante, Marcello, Kepos e Peripatos. Contributo alla storia dell'aristotelismo antico (Naples 1999)

Granger, Herbert, Aristotle's Idea of the Soul (Dodrecht/Boston/London 1996)

Gregory, Tullio, «Studi sull'Atomismo del Seicento. I: Sebastiano Basson», Giornale Critico della Filosofia Italiana 43 vol. 18 (1964) 38-65

Inwood, Brad/Gerson, Lloyd P. (eds), The Epicurus Reader: Selected Writings and Testimonia (Indianapolis 1994)

Isnardi Parente, Margherita (ed.), Senocrate - Ermodoro, Frammenti (Neaples 1982)

Kahn, Charles H., "Aristotle on Thinking”, in: Martha C. Nussbaum/Amélie Oksenberg Rorty (eds), Essays on Aristotle's De Anima (Oxford 1992) 359-379

Kessler, Eckhard, «Selbstorganisation in der Naturphilosophie der Renaissance», Selbstorganisation. Jahrbuch für Komplexität in den Natur-, Sozial- und Geisteswissenschaften 3 (1992) 15-29

Johnson, Monte/Wilson, Catherine, "Lucretius and the history of science" in: Stuart Gillespie/Philip Hardie (eds), The Cambridge Companion to Lucretius (Cambridge 2007) 131-148

Lloyd, Geoffrey E. R., Polarity and Analogy. Two Types of Argumentation in Early Greek Thought (Cambridge 1971)

Lloyd, Geoffrey E. R., "Aspects of the Relationship between Aristotle's Psychology and his Zoology", in: Martha C. Nussbaum/Amélie Oksenberg Rorty (eds), Essays on Aristotle's De Anima (Oxford 1992) 147-167

Lo Presti, Roberto, In forma di senso. La dottrina encefalocentrica del trattato ippocratico Sulla malattia sacra nel suo contesto epistemologico (Rome 2008)

Mansfeld, Jaap, «Epicurus Peripateticus», in: Antonia Alberti (ed.), Realtà e ragione. Studi di filosofia antica (Florence 1994) 29-47

Manzo, Silvia A., "Francis Bacon and Atomism: A Reappraisal" in Christoph Lüthy/ John E. Murdoch/William R. Newman (eds), Late Medieval and Early Modern Corpuscular Matter Theories (Leiden 2001) 209-243

Meinel, Christoph, "Early 17th-Century Atomism. Theory, Epistemology, and the Insufficiency of Experiment", Isis 79 n. 296 (1988) 68-103

Melville, Ronald (transl. by), Lucretius, On the Nature of the Universe, with an Introduction and Notes by Don and Peta Fowler (Oxford 1997)

Merchant, Carolyn, The Death of Nature: Women, Ecology, and the Scientific Revolution (New York 1980)

Merchant, Carolyn, "The Scientific Revolution and the Death of Nature", Isis 97 n. 3 (2006) 513-533

Moraux, Paul, Der Aristotelismus bei den Griechen, 2 Bde. (Berlin/New York 1973)

Nussbaum, Martha C., Aristotle's De Motu Animalium (Princeton, NJ 1978) 
Nussbaum, Martha C./Oksenberg Rorty, Amélie (eds), Essays on Aristotle's De Anima (Oxford 1992)

Paladini, Maria Antonietta, Lucrezio e l'epicureismo tra Riforma e Controriforma (Naples 2011)

Passannante, Gerard, The Lucretian Renaissance. Philology and the Afterlife of Tradition (Chicago/London 2011)

Patzig, Günther, «Körper und Geist bei Aristoteles - zum Problem des Funktionalismus», in: Dorothea Frede/Burkhard Reis (eds), Body and Soul in Ancient Philosophy (Berlin/New York 2009) 249-266

Pigeaud, Jackie, «La physiologie de Lucrèce», Revue des Études Latines 58 (1980) $176-200$

Pigeaud, Jackie, La maladie de l'âme. Etude sur la relation de l'âme et du corps dans la tradition médico-philosophique antique (Paris 1981)

Prosperi, Valentina, Di soavi licor gli orli del vaso: la fortuna di Lucrezio dall'Umanesimo alla Controriforma (Turin 2004)

Pupo, Spartaco, L'anima immortale in Telesio. Per una storia delle interpretazioni (Cosenza 1999)

Putnam, Hilary, "Philosophy and our Mental Life", in: Hilary Putnam, Mind, Language and Reality. Philosophical Papers, vol. 2 (Cambridge 1975) 291-303

Rechenauer, Georg, «Demokrits Seelenmodell und die Prinzipien der atomistischen Physik», in: Dorothea Frede/Burkhard Reis (eds), Body and Soul in Ancient Philosophy (Berlin/New York 2009) 111-142

Rees, Graham, "Francis Bacon's Semi-Paracelsian Cosmology", Ambix 22 (1975a) 81-101

Rees, Graham, "Francis Bacon's Semi-Paracelsian Cosmology and the Great Instauration", Ambix 22 (1975b) 161-173

Rees, Graham, "Matter Theory: A Unifying Factor in Bacon's Natural Philosophy?", Ambix 24 (1977) 110-125

Rees, Graham, “Atomism and 'Subtlety' in Francis Bacon's Philosophy”, Annals of Science 37 (1980) 549-571

Rees, Graham, "Francis Bacon and spiritus vitalis", in: Marta Fattori/Massimo Luigi Bianchi (eds), Spiritus. IV Colloquio Internazionale del Lessico Intellettuale Europeo (Roma, 7-9 gennaio 1983) (Rome 1984) 265-281

Schiesaro Alessandro, Simulacrum et imago: gli argomenti analogici nel De rerum natura (Pisa 1990)

Schmitt, Charles B., "Towards a Reassessment of Renaissance Aristotelianism", History of Science 11 (1973) 159-193

Schrijvers, Piet H., «Le regard sur l'invisible. Étude sur l'emploi de l'analogie dans l'œuvre de Lucrèce», in: Olof Gigon (ed.), Lucrèce. XXIV Entretiens Hardt sur l'Antiquité Classique (Geneva 1978) 77-121

Schrijvers, Piet H., Lucrèce et les sciences de la vie (Leiden/Boston/Köln 1999)

Schuhmann, Karl, “Telesio's Concept of Matter”, in: Piet Steenbakkers/Cees Leijenhorst (eds), Karl Schuhmann. Selected papers on Renaissance philosophy and on Thomas Hobbes (Dordrecht 2004) 99-116

Sedley, David, Lucretius and the Transformation of Greek Wisdom (Cambridge 1998)

Skrbina, David, Panpsychism in the West (Cambridge, MA 2005) 
Snyder, Jane McIntosh, Puns and Poetry in Lucretius' De Rerum Natura (Amsterdam 1980)

Sorabji, Richard, "Body and Soul in Aristotle", Philosophy 49 (1974) 63-89

Sorabji, Richard, Intentionality and Physiological Processes: Aristotle's Theory of Sense-Perception, in: Martha C. Nussbaum/Amélie Oksenberg Rorty (eds), Essays on Aristotle's De Anima (Oxford 1992) 195-225

Sperber, Dan, Explaining Culture: A Naturalistic Approach (Oxford 1996a)

Sperber, Dan, "Why are perfect animals, hybrids, and monsters food for symbolic thought", Method \& Theory in the Study of Religion 8-2 (1996b) 143-169

Taylor, C. C. W. (ed.), The Atomists: Leucippus and Democritus. Fragments (Toronto/ Buffalo/London 1999)

Tutrone, Fabio, "Between Atoms and Humours: Lucretius' Didactic Poetry as a Model of Integrated and Bifocal Physiology", in: Manfred Horstmanshoff/Helen King/ Claus Zittel (eds), Blood, Sweat and Tears. The Changing Concepts of Physiology from Antiquity into Early Modern Europe (Leiden 2012a) 83-102

Tutrone, Fabio, Filosofi e animali in Roma antica: Modelli di animalità e umanità in Lucrezio e Seneca (Pisa 2012b)

Usener, Hermann, Epicurea (Leipzig 1887)

Vallance, John T., The Lost Theory of Asclepiades of Bithynia (Oxford 1990)

Walker, Daniel P., "Francis Bacon and Spiritus", in: Allen G. Debus (ed.), Science, Medicine and Society in the Renaissance: Essays to Honor Walter Pagel, 2 vols. (London 1972) II: 121-130

Walker, Daniel P., "Medical Spirits and God and the Soul", in: Marta Fattori/Massimo Luigi Bianchi (eds.), Spiritus. IV Colloquio Internazionale del Lessico Intellettuale Europeo (Roma, 7-9 gennaio 1983) (Rome 1984) 223-244

Wilkes, Kathleen V., "Psuchē versus the Mind", in: Martha C. Nussbaum/Amélie Oksenberg Rorty (eds), Essays on Aristotle's De Anima (Oxford 1992) 109-127

Witt, Charlotte, "Dialectic, Motion, and Perception: De Anima Book I", in: Martha C. Nussbaum/Amélie Oksenberg Rorty (eds), Essays on Aristotle's De Anima (Oxford 1992) 169-183 